\title{
The shifting mosaic of ice-wedge degradation and stabilization in response to infrastructure and climate change, Prudhoe Bay Oilfield, Alaska, USA ${ }^{1}$
}

\author{
Mikhail Kanevskiy, Yuri Shur, D.A. (Skip) Walker, Torre Jorgenson, Martha K. \\ Raynolds, Jana L. Peirce, Benjamin M. Jones, Marcel Buchhorn, Georgiy Matyshak, \\ Helena Bergstedt, Amy L. Breen, Billy Connor, Ronald Daanen, Anna Liljedahl, \\ Vladimir E. Romanovsky, and Emily Watson-Cook
}

\begin{abstract}
We studied processes of ice-wedge degradation and stabilization at three sites adjacent to road infrastructure in the Prudhoe Bay Oilfield, Alaska, USA. We examined climatic, environmental, and subsurface conditions and evaluated vulnerability of ice wedges to thermokarst in undisturbed and road-affected areas. Vulnerability of ice wedges strongly depends on the structure and thickness of soil layers above ice wedges, including the active, transient, and intermediate layers. In comparison with the undisturbed area, sites adjacent to the roads had smaller average thicknesses of the protective intermediate layer $(4 \mathrm{~cm}$ vs. $9 \mathrm{~cm}$ ), and this layer was absent above almost $60 \%$ of ice wedges (vs. $\sim 45 \%$ in undisturbed areas). Despite the strong influence of infrastructure, ice-wedge degradation is a reversible process. Deepening of troughs during ice-wedge degradation leads to a substantial increase in mean annual ground temperatures but not in thaw depths. Thus, stabilization of ice wedges in the areas of cold continuous permafrost can occur despite accumulation of snow and water in the troughs. Although thermokarst is usually more severe in flooded areas, higher plant productivity, more litter, and mineral material (including road dust) accumulating in the troughs contribute to formation of the intermediate layer, which protects ice wedges from further melting.

Key words: permafrost, thermokarst, ground ice, cryostratigraphy, active layer, transient layer, intermediate layer.
\end{abstract}

Received 26 May 2021. Accepted 25 November 2021.

M. Kanevskiy, Y. Shur, B.M. Jones, H. Bergstedt,* and B. Connor. Institute of Northern Engineering, University of Alaska Fairbanks, PO Box 755910, Fairbanks, AK 99775, USA.

D.A. (Skip) Walker, M.K. Raynolds, J.L. Peirce, and E. Watson-Cook. Institute of Arctic Biology, University of Alaska Fairbanks, PO Box 757000, Fairbanks, AK 99775, USA.

T. Jorgenson. Alaska Ecoscience, Fairbanks, Alaska, AK 99709, USA.

M. Buchhorn. VITO, Boeretang 200, BE-2400 MOL, Belgium.

G. Matyshak. Department of Soil Science, Lomonosov Moscow State University, Moscow 119991, Russia.

A.L. Breen. International Arctic Research Center, University of Alaska Fairbanks, AK 99775, USA.

R. Daanen. Alaska Department of Natural Resources, Geological and Geophysical Surveys, Fairbanks, AK 99709, USA.

A. Liljedahl. Woodwell Climate Research Center, Falmouth, MA 02540, USA.

V.E. Romanovsky. Geophysical Institute, University of Alaska Fairbanks, AK 99775, USA.

Corresponding author: Mikhail Kanevskiy (e-mail: mkanevskiy@alaska.edu).

*Present address: b.geos GmbH Industriestrasse 1, 2100 Korneuburg, Austria.

${ }^{1}$ This article is part of a Virtual Special Issue entitled: Terrestrial Geosystems, Ecosystems, and Human Systems in the Fast-Changing Arctic.

(C) 2022 The Author(s). This work is licensed under a Creative Commons Attribution 4.0 International License (CC BY 4.0), which permits unrestricted use, distribution, and reproduction in any medium, provided the original author(s) and source are credited. 
Résumé : Les auteurs ont étudié les processus de dégradation et de stabilisation des coins de glace sur trois sites adjacents à l'infrastructure routière dans le champ pétrolifère de Prudhoe Bay, en Alaska, États-Unis. Ils ont examiné les conditions climatiques, environnementales et de sous-surface et évalué la vulnérabilité des coins de glace au thermokarst dans des zones non perturbées et affectées par les routes. La vulnérabilité des coins de glace dépend fortement de la structure et de l'épaisseur des couches de sol au-dessus des coins de glace, y compris les couches actives, transitoires et intermédiaires. Par rapport à la zone non perturbée, les sites adjacents aux routes présentaient des épaisseurs moyennes plus faibles de couche intermédiaire protectrice $(4 \mathrm{~cm}$ contre $9 \mathrm{~cm})$, et cette couche était absente au-dessus de presque $60 \%$ des coins de glace (contre 45 \% dans les zones non perturbées). Malgré la forte influence des infrastructures, la dégradation des coins de glace est un processus réversible. L'approfondissement des cuvettes pendant la dégradation des coins de glace entraîne une augmentation substantielle des températures annuelles moyennes du sol, mais pas des profondeurs de dégel. Ainsi, la stabilisation des coins de glace dans les zones de pergélisol froid continu peut se produire malgré l'accumulation de neige et d'eau dans les cuvettes. Bien que le thermokarst soit généralement plus sévère dans les zones inondées, une productivité végétale plus élevée, davantage de litière et de la matière minérale (y compris la poussière des routes) s'accumulant dans les cuvettes contribuent à la formation de la couche intermédiaire, qui protège les coins de glace d'une fonte plus importante. [Traduit par la Rédaction]

Mots-clés : pergélisol, thermokarst, glace de sol, cryostratigraphie, couche active, couche transitoire, couche intermédiaire.

\section{Introduction}

The Prudhoe Bay Oilfield (PBO) is located on the Arctic Coastal Plain of Alaska, USA, near the Beaufort Sea coast. The upper permafrost of the Arctic Coastal Plain contains significant amounts of excess ground ice (up to $80 \%$ by volume), represented mainly by lenses of segregated ice and large ice wedges (Leffingwell 1919; Brown and Sellmann 1973; Jorgenson 2011; Kanevskiy et al. 2013). High ground-ice content and a landscape rife with wedge ice makes this area vulnerable to the effects of thermokarst and thermal erosion. During the last decades, widespread degradation of ice wedges has been observed across the Arctic, including the Arctic Coastal Plain of Alaska, and in the PBO (Shur et al. 2003; Jorgenson et al. 2006, 2015; Kokelj et al. 2014; Lara et al. 2015; Raynolds et al. 2014; Walker et al. 2014, 2015, 2022; Pollard et al. 2015; Christiansen et al. 2016; Liljedahl et al. 2016; Swanson 2016; Frost et al. 2018; Farquharson et al. 2019; Abolt et al. 2020).

Ice-wedge degradation, which strongly affects the environment and is extremely hazardous for infrastructure, can be triggered by climatic fluctuations (Jorgenson et al. 2015; Liljedahl et al. 2016), wildfires (Jones et al. 2015), human activities (Walker et al. 1987, 2014, 2015; Raynolds et al. 2014; Kanevskiy et al. 2016), or other factors that lead to an increase in a thickness of the active layer. The recent climate-driven increases in active-layer thickness, which could result in widespread ice-wedge degradation in northern Alaska, were probably related to exceptionally warm and wet summers of 1989 and 1998 (Jorgenson et al. 2015), and further influenced by the summer of 2012 (Walker et al. 2022). Within the built environment in ice-rich permafrost regions, ice-wedge thermokarst often starts as a result of destruction of peat and moss cover, accumulation of snow around buildings, embankments, and snow fences, or construction activities. For example, gravel pads and road embankments change the hydrological regime dramatically, and accumulation of surface water, dust, and snow near embankments may cause or enhance ice-wedge degradation (Walker et al. 1987; Raynolds et al. 2014). 
Fig. 1. Stages of the ice-wedge degradation and stabilization (modified from Kanevskiy et al. 2017). Stages detected in this study are framed by the brown rectangle.

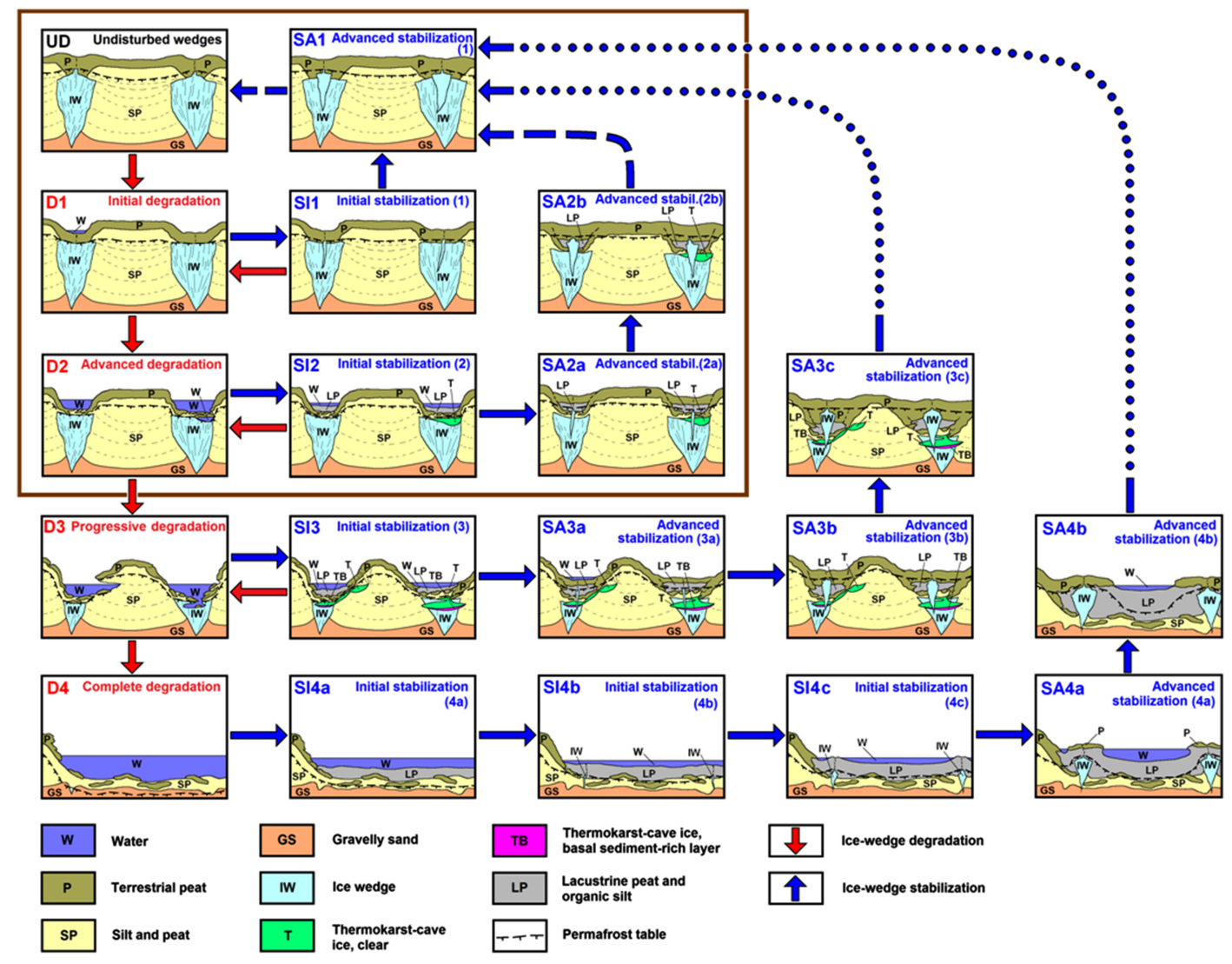

Ice-wedge dynamics are driven by a quasi-cyclic process, which includes five main stages: Undegraded wedges (UD) - Degradation-initial (DI) - Degradation-advanced (DA) Stabilization-initial (SI) - Stabilization-advanced (SA) (Jorgenson et al. 2006, 2015). A conceptual model depicting these stages suggested initially by Jorgenson et al. (2006) was later modified by Kanevskiy et al. (2017) (modified version of the latter is presented in Fig. 1). Initial degradation is caused by extreme weather conditions (e.g., exceptionally warm and wet summers) or physical disturbance, which leads to increase in the active-layer thickness (ALT) and partial thawing of ice wedges with formation of shallow troughs. Water impoundment and additional snow accumulation in troughs leads to further thawing of ice wedges and deepening of troughs. Interacting factors such as climate, topography, vegetation, surface and groundwater, and soil properties create positive and negative feedbacks to icewedge degradation (Jorgenson et al. 2006, 2010, 2015; Shur and Jorgenson 2007; Kanevskiy et al. 2017). As a result of advanced ice-wedge thermokarst, new surface flow pathways develop with the formation of trough drainage networks, which cause significant hydrological changes in the Arctic landscapes (Liljedahl et al. 2016) and ultimately alter the ground thermal regime and the ecosystem of ice-wedge polygonal terrain (Godin et al. 2016).

The processes of ice-wedge degradation, stabilization, and recovery are determined by interactions between the active layer and the underlying transition zone of the upper permafrost, which includes the transient layer (TL) and intermediate layer (IL) (Shur 1988; 
French and Shur 2010; Shur et al. 2011; Murton 2013). The uppermost part of the transition zone - the transient layer - is defined as a layer of soil that belongs to the permafrost for several years and joins the active layer in the years with deeper seasonal thaw (Shur 1975; Shur et al. 2005, 2011). In mineral soils, the TL thickness can be as much as $30 \%$ of the annual mean ALT. The IL, which constitutes the lower part of the transition zone, forms due to a gradual decrease in the ALT, mostly as a result of accumulation of organic matter after termination or slow-down of sedimentation. This long-term process transforms the initial TL and a part of the initial active layer into a perennially frozen state (Shur 1988; Shur et al. 2011).

Accumulation of organic matter in the troughs developing on top of degrading wedges eventually leads to a decrease in the ALT and formation of the ice-rich IL, protecting ice wedges from further degradation (Jorgenson et al. 2006, 2015; Kanevskiy et al. 2016, 2017). The thickness of the IL above stabilized ice wedges is usually much greater than that in undisturbed conditions. This makes the permafrost more resistant to external changes, such as climate change and disturbance. As a result, partially degraded ice wedges can be very stable until large volumes of wedge ice accumulate within the IL, increasing the risk of future degradation, especially in case of further climate warming (Kanevskiy et al. 2016, 2017).

Under certain conditions, ice-wedge degradation may result in complete melting of ice wedges and formation of large thermokarst lakes (Raynolds et al. 2014; Kanevskiy et al. 2017). However, the probability of such transformation is much higher in areas with warmer permafrost, like the Seward Peninsula in Alaska, USA (Shur et al. 2012).

We have studied the structure and properties of the upper permafrost and processes of ice-wedge degradation and stabilization within the PBO for many years (Walker et al. 1980, 1987, 2014, 2015, 2016, 2018, 2022; Jorgenson 2011; Kanevskiy et al. 2013, 2016, 2017; Raynolds et al. 2014; Jorgenson et al. 2015; Shur et al. 2016; Koch et al. 2018; Wickland et al. 2020). This area has been strongly affected by development since the late 1960s, which resulted in both direct and indirect effects to the environment (Raynolds et al. 2014; Walker et al. 2022). The direct effects include the "footprint" of various types of engineered structures (e.g., roads, embankments, pipelines, mines, and airports). The indirect impacts include road dust, road-related flooding, off-road vehicle trails, and infrastructure-related thermokarst (Walker et al. 1987, 2022).

Infrastructure-induced ice-wedge thermokarst, the second most extensive indirect effect after flooding, began developing in roadside areas soon after construction of the roads in the 1960s and 1970s. It was caused mainly by an increase in the ALT triggered by flooding, which occurs periodically due to the construction of road embankments; accumulation of dust, which kills vegetation and changes soil thermal properties; and additional snow accumulation near the embankment, which results in higher soil temperatures (Raynolds et al. 2014; Kanevskiy et al. 2016; Walker et al. 2022). For several decades ice-wedge thermokarst affected relatively small areas along the roads (Walker et al. 1987), but since the 1990s the affected area has increased dramatically, not only as a result of an increase in the development footprint, but due to climatic changes, which have also affected areas located far away from infrastructure (Raynolds et al. 2014; Walker et al. 2022).

In this study, we investigate processes of ice-wedge degradation and stabilization in relation to road infrastructure and climate in several study sites within the PBO, which include relatively undisturbed areas and areas affected by development. The objectives of this study are to (i) examine ground ice, soil stratigraphy, and environmental characteristics within the three study sites; (ii) determine stages of ice-wedge degradation and stabilization, evaluate vulnerability of ice wedges to thermokarst, and compare vulnerability levels at different study sites; and (iii) analyze the main factors affecting ice-wedge degradation and stabilization in undisturbed (affected only by climate change) and disturbed (affected 
Fig. 2. Locations of study sites: JS, Jorgenson Site; CS, Colleen Site; and AS, Airport Site.

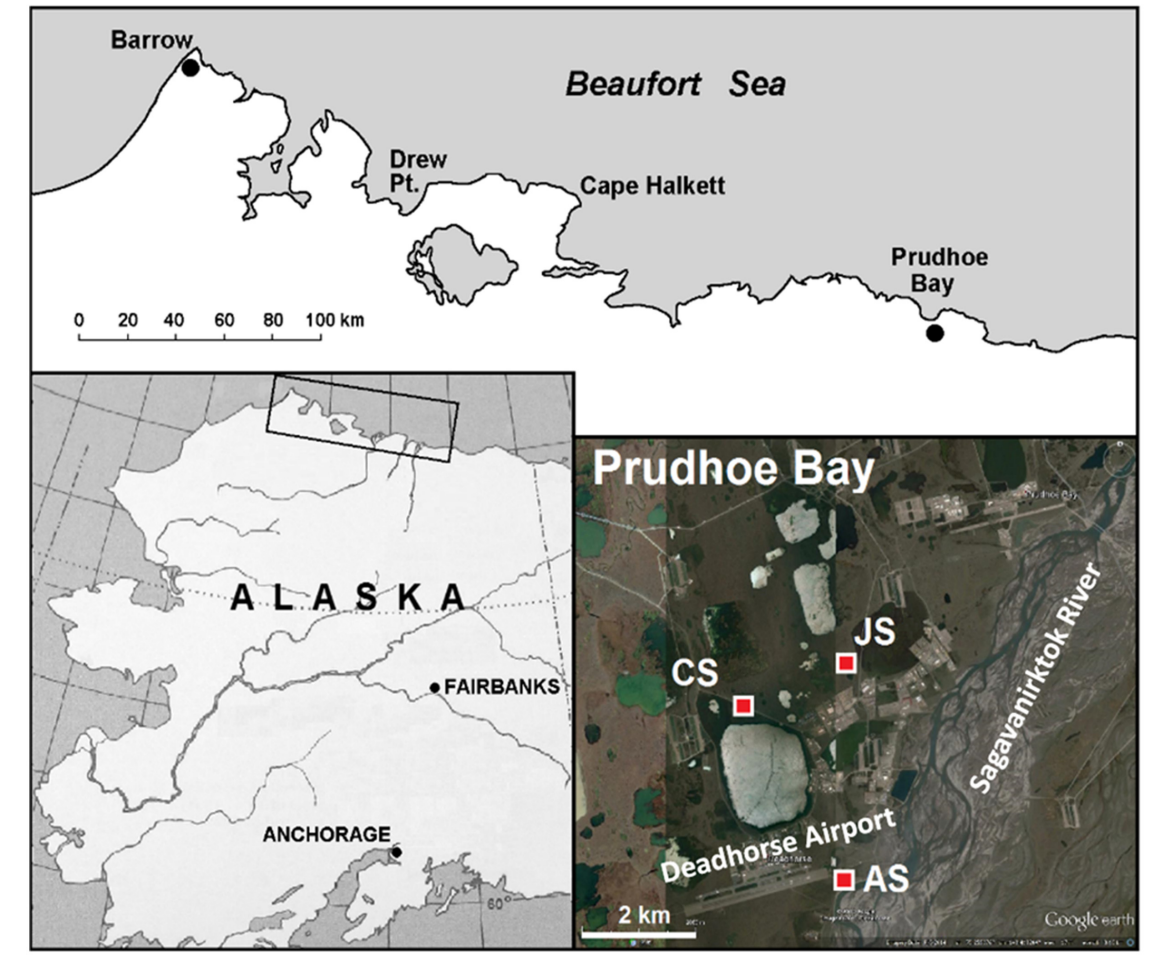

also by road infrastructure) areas of the PBO. Our findings have implications for guiding future infrastructure development in ice-rich permafrost regions in the Arctic.

\section{Study areas}

Field work was performed from 2011 to 2016 at three study sites in the PBO (Fig. 2): relatively undisturbed Jorgenson Site (JS) and two sites located in areas affected by development, Colleen Site (CS), and Airport Site (AS) (Walker et al. 2014, 2015, 2016, 2018, 2022; Jorgenson et al. 2015; Kanevskiy et al. 2017; Koch et al. 2018; Wickland et al. 2020). These sites are located on the Arctic Coastal Plain close to the Beaufort Sea coast of Alaska (BSCA). The surficial deposits of the Arctic Coastal Plain include Quaternary sediments of various origins (fluvial, marine, eolian, and deltaic), which have been significantly modified by thermokarst, lacustrine, and paludification processes, resulting in an abundance of lake-basin deposits (Brown and Sellmann 1973; Rawlinson 1993; Jorgenson 2011; Kanevskiy et al. 2013). The BSCA is a region of cold continuous permafrost, whose thickness generally varies from 200 to $400 \mathrm{~m}$, but in the Prudhoe Bay area it exceeds $600 \mathrm{~m}$ (Lachenbruch et al. 1988; Jorgenson 2011). The upper permafrost is characterized by extremely high ground-ice content and contains large ice wedges (Leffingwell 1919; Brown and Sellmann 1973; Black 1983; Jorgenson 2011; Kanevskiy et al. 2013).

Climatic data from National Oceanic and Atmospheric Administration summarized for the 1981-2010 period (The Alaska Climate Research Center, http://climate.gi.alaska.edu/ Climate/Normals) show that the mean annual air temperature (MAAT) at Prudhoe Bay was $-11.1^{\circ} \mathrm{C}$, annual precipitation was $102.6 \mathrm{~mm}$, and annual snowfall was $85.6 \mathrm{~cm}$. The freezing index at Prudhoe Bay, averaged for the $1981-2010$ period, was $-4637.6{ }^{\circ} \mathrm{C}$-day, whereas thawing index was $593.3^{\circ} \mathrm{C}$-day. 
Despite a recent increase in MAAT and mean annual ground temperature (MAGT) (Romanovsky et al. 2016, 2017), no significant increase in the mean ALT has been reported during the last decades for numerous study sites located within the Alaskan Arctic Coastal Plain (Streletskiy et al. 2008, Shiklomanov et al. 2012), although a minor increasing trend in the ALTs for some of the Circumpolar Active Layer Monitoring (CALM) grids has been noticeable since $\sim 2010$ (Fig. $\mathbf{S 1}^{2}$ ). According to the CALM database (https:// www2.gwu.edu/ calm/data/data-links.htm), the mean ALTs at the Deadhorse site (CALM site U6; $100 \times 100 \mathrm{~m}$; 121 measuring points) in 1996-2019 have varied from 55.5 to $72.8 \mathrm{~cm}$ with an average value of $66.0 \mathrm{~cm}$. This means that the maximum thickness of the transient layer during some years may, in principle, exceed $17 \mathrm{~cm}$ (approximately 26\% of the average ALT), which is close to a general estimation of 30\% (Shur et al. 2005). The highest ALT values at the CALM site $(>70 \mathrm{~cm})$ were reported for 1998-1999, 2013-2017, and 2019, whereas the lowest values $(<60 \mathrm{~cm})$ were reported for 2005,2007 , and 2009 . The ALT values depend on summer temperatures (Fig. S2 ${ }^{2}$ ), but other factors also strongly affect ALT dynamics, including snow depth, summer precipitation, flooding, and changing albedo. Although the time of thaw-depth measurements in 1997-2017 varied from mid-August to mid-September $\left(\right.$ Fig. $\mathrm{S2}^{2}$ ), there was not a close correlation between the dates of measurements and thaw depths on an annual basis.

All three study areas are located within the ancient, abandoned floodplain of the Sagavanirktok River (Walker et al. 2015). In terms of surficial geology, JS and CS are underlain by alluvial plain deposits, which include pebbly sand and gravel alluvial deposits overlain by eolian sandy silt and sometimes organic-rich thaw-lake deposits, and AS is underlain by ice-rich thaw-lake deposits, which include peat and pebbly silt or fine sand (Rawlinson 1993). The JS is relatively undisturbed, in contrast with the other sites. The CS has been strongly affected by the Spine Road (the oldest road in the Prudhoe Bay area, which was constructed in 1969) through road-restricted drainage that has caused annual flooding events, changes in snow accumulation, and heavy dust accumulation. The AS has also been similarly affected by the Dalton Highway and the runway of the Deadhorse Airport, as well as by catastrophic flooding from the Sagavanirktok River, which occurred in this area in Spring 2015 (Shur et al. 2016). Analysis of aerial photographs obtained from 1949 to 2013 reveals that before development, all study areas were part of a relatively homogeneous plain with low-centered polygons, scattered thermokarst pits and ponds, and larger thaw lakes and drained thaw-lake basins.

\section{Methods}

\section{Sampling strategy}

The Jorgenson Site (JS) $\left(70.229^{\circ} \mathrm{N}, 148.419^{\circ} \mathrm{W}\right)$ was established in June 2011 (Fig. 2). It consists of 18 monitoring plots along a $250 \mathrm{~m}$ transect (Fig. S3 ${ }^{2}$ ) representing five stages of ice-wedge degradation/stabilization and the centers of ice-wedge polygons. Additional coring locations were located off the transect to collect more information on some stages of ice-wedge dynamics. Work included surveying ground- and water-surface elevations, permafrost coring for soil stratigraphy and ground-ice descriptions, vegetation sampling, and ground-based LiDAR scanning to develop a high-resolution digital elevation model. For the JS, field study methods were described in previous publications (Jorgenson et al. 2015, Kanevskiy et al. 2017).

The Colleen Site (CS) $\left(70.223^{\circ} \mathrm{N}, 148.471^{\circ} \mathrm{W}\right)$ was established in August 2014 on both sides of the Spine Road to quantify the effects of road-related disturbances to the permafrost,

\footnotetext{
${ }^{2}$ Supplementary data are available with the article at https://doi.org/10.1139/as-2021-0024.
} 
landforms, and vegetation (Fig. 2). It includes two $200 \mathrm{~m}$ transects and 29 permanent vegetation plots (Fig. 3A). The methods of surveying the vegetation, soil, and environmental variables were described in detail in two data reports (Walker et al. 2015, 2018) and summarized by Walker et al. (2022). There are no culverts for a long section of road near the CS, and the elevated road embankment is a barrier to drainage of water from the southwest to northeast side of the road. Transect 2 (T2) is on the southwest side, which is often flooded in early summer. Transect 1 (T1) is located on the northeast, relatively well-drained side of the road. Vegetation, environmental, and soil studies (including coring of the upper permafrost) were conducted along the transects in the centers and troughs of the polygons at distances from the road of $5,10,25,50,100$, and $200 \mathrm{~m}$.

At the Airport Site (AS) $\left(70.196^{\circ} \mathrm{N}, 148.425^{\circ} \mathrm{W}\right)$ (Fig. 2), three $100 \mathrm{~m}$ transects and 27 permanent vegetation plots were established in August 2015 near the Deadhorse Airport and the northern terminus of the Dalton Highway at Milepost 414 (Walker et al. 2016). Like the CS, the road is a barrier to water movement from the periodically flooded northwest side of the road toward the southeast side of the road. Transect 3 (T3) is in an area of well-drained polygons with deep, well-developed relatively dry ice-wedge troughs between the road and the Sagavanirktok River (Fig. 3B). Transect 4 (T4) was established in heavily disturbed flooded area northwest of the Dalton Highway. Gravel prevented permafrost coring along T4. Transect 5 (T5) was established to provide better options for permafrost coring on the west side of the highway (Fig. 3C). Similar to the CS, vegetation, environmental, and soil studies were conducted along the AS transects in the centers and troughs of the polygons at distances from the highway of $5,10,25,50$, and $100 \mathrm{~m}$. Coring of the upper permafrost was performed along T3 and T5 at differing distances from the highway mainly in the ice-wedge troughs; two boreholes were drilled in the polygon centers (one at each transect). In this paper, we focus mainly on the results of studies performed at T3 and T5 (Fig. 3B and C).

The location and elevation of all transect points, boreholes, vegetation plots and other reference points at the JS, CS, and AS were measured using a Topcon RTK (real time kinematic) GPS Hyperlite+ and robotic Topcon IS-3 surveying instrument.

\section{Frozen soil and ground ice}

Methods of the ground-ice investigations in the study areas were described by Jorgenson et al. (2015), Kanevskiy et al. (2017), and Walker et al. (2014, 2015). Numerous boreholes up to $3.5 \mathrm{~m}$ deep were drilled with a SIPRE corer $(7.5 \mathrm{~cm}$ in diameter). Before coring, a soil plug was extracted from above the frozen soil and described to note the depth of the organic horizons, soil texture, and depth of thaw. Soil samples were collected to determine soil properties. The ice content of the soil was determined from an initial weight of soil in frozen state and after oven-drying $\left(90^{\circ} \mathrm{C}, 72 \mathrm{~h}\right)$. Both gravimetric (GMC) and volumetric moisture contents (VMC) were calculated for borehole cores. Volumes of frozen samples were determined in the field by measuring the length and diameter of the cores.

At each transect, one to six boreholes were drilled in polygon centers to study cryostratigraphy. The boreholes in ice-wedge-polygon centers were drilled to a depth where gravel was encountered, preventing deeper drilling. Numerous boreholes were drilled in ice-wedge troughs to evaluate the depth to massive ground ice and dimensions of massive-ice bodies, which consisted of wedge ice and (or) thermokarst-cave ice. The term thermokarst-cave ice (TCI) was suggested by Shumskii (1959) for massive ice formed by the freezing of water trapped in underground cavities that were cut into permafrost by running water. The TCI bodies commonly form within and next to ice wedges, are oriented horizontally, and have been described in numerous publications (sometimes referred to as pool ice) (Mackay 1997, 2000; Shur et al. 2004; Bray et al. 2006; Fortier et al. 2008; Kanevskiy et al. 2008, 2013, 2017; 
Fig. 3. Locations of transects (T, bold white lines), permanent plots (white squares), and boreholes (white circles with black centers, yellow labels) at (A) Colleen Site (T1, T2), (B) Airport Site (T3, T4), and (C) Airport Site (T5). $\mathrm{T} 1$ and T2 are each $200 \mathrm{~m}$ long. T3, T4, and T5 are $100 \mathrm{~m}$ long. Base image is black and white World View image (9 July 2010). Modified from Walker et al. (2018).
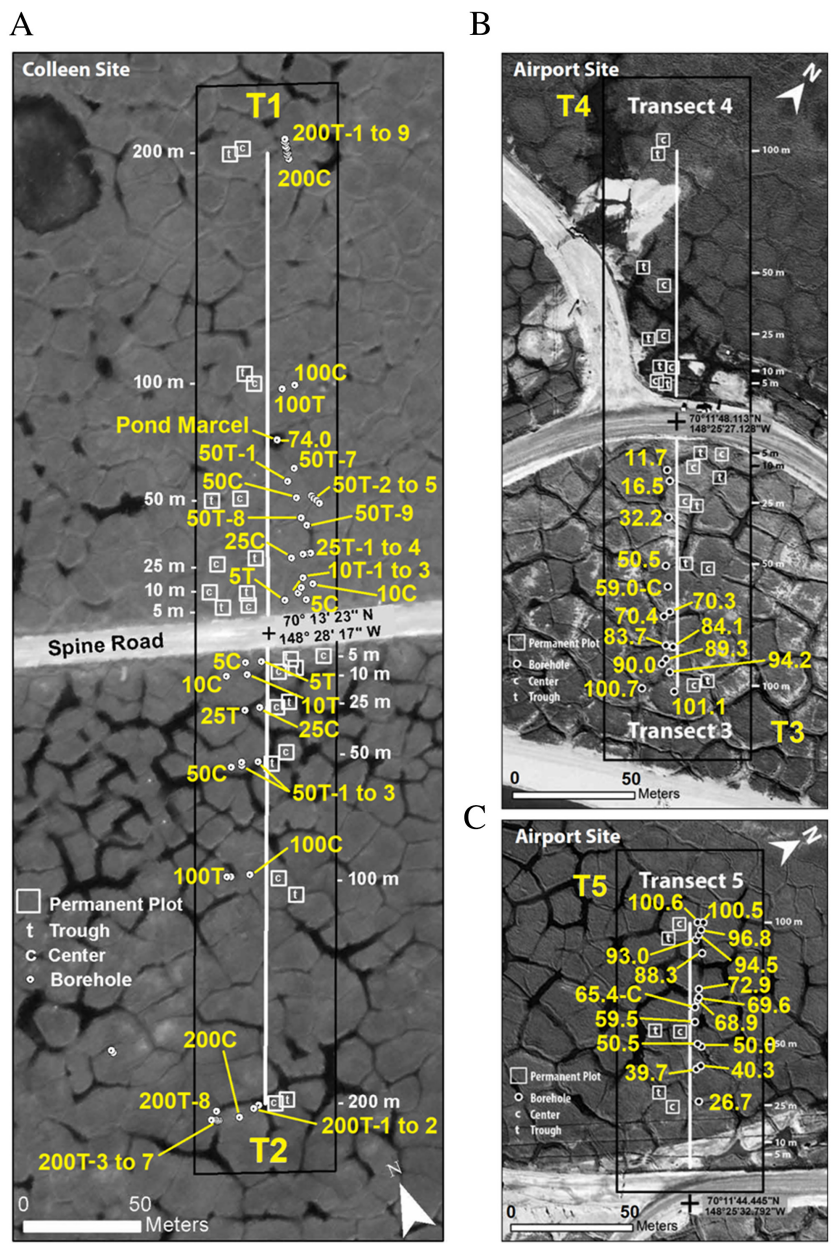

Murton 2013). Massive ice and cryostructures (patterns formed by inclusions and lenses of pore and segregated ice in the frozen soil) were described using classifications adapted from Russian and North American literature (French and Shur 2010; Kanevskiy et al. 2013; Murton 2013 and references therein).

At the JS, 56 boreholes were drilled in early June 2011 and 57 boreholes in late July 2012 (113 boreholes in total), and 94 samples were taken to estimate moisture contents of frozen soils. At the CS, 57 boreholes were drilled in August 2014 at T1 and T2, and one borehole in March 2016 at T1; 140 samples were taken to estimate moisture contents. At the AS, 28 boreholes were drilled in September 2015 at T3 and T5, and two boreholes in March 2016 at T5; 40 samples were taken to estimate moisture contents.

\section{Climatic and environmental factors}

Climatic and environmental factors evaluated for this study included air temperatures, microtopography, water and snow depths, and vegetation. These factors control active-layer thickness and soil temperatures and, therefore, affect the process of ice-wedge degradation. 
Methods of characterization of the JS were described by Jorgenson et al. (2015). Ground- and water-surface elevations were measured every $1 \mathrm{~m}$ along the $250 \mathrm{~m}$ transect using an auto-level and rod at $1 \mathrm{~cm}$ resolution. Thaw, water, and snow depths were measured with the metal 1.2-m-long probe to the nearest $1 \mathrm{~cm}$; thaw depths under the water were measured from the soil surface. Air and soil temperatures were measured periodically. Vegetation cover at the JS was described at the 18 intensive plots using the point-intercept method.

The methods for evaluating the vegetation types, microrelief features, soil, and environmental variables at the CS and AS were described by Walker et al. $(2014,2015,2022)$. Measurements of elevation, thaw depth, water and snow depths, and plant canopy height were made every $1 \mathrm{~m}$ up to $100 \mathrm{~m}$ from the road along all CS and AS transects. At the CS, additional measurements were performed every $5 \mathrm{~m}$ from 100 to $200 \mathrm{~m}$ from the road along $\mathrm{T} 1$ and T2. Thickness of the surface dust layer was measured at $5 \mathrm{~m}$ intervals. Soil and air temperature Maxim iButton ${ }^{\circledR}$ temperature loggers were installed at $0,-20$ and $-40 \mathrm{~cm}$ soil depths below the surface (typically below the moss cover) and above ground at 10, 20, 50 and $100 \mathrm{~cm}$ in the air to monitor soil and air temperatures at all permanent vegetation plots along T1, T2, T3, and T4 (in August 2014 and 2015 at the CS, and in August 2015 at the AS).

\section{Stages of ice-wedge degradation/stabilization}

To identify stages of ice-wedge degradation/stabilization, we evaluate various surface (microrelief, depth of ice-wedge troughs, water depth, and vegetation) and subsurface characteristics (depth to massive ice, thickness of the intermediate layer) based on our previously developed approaches and conceptual models (Jorgenson et al. 2006, 2015; Raynolds et al. 2014; Kanevskiy et al. 2017). The conceptual model depicting stages of quasi-cyclic processes of ice-wedge degradation and stabilization is presented in Fig. 1; characteristics of the main stages typical of the Prudhoe Bay study area are presented in Table 1.

\section{Evaluation of vulnerability of ice wedges to thermokarst}

Vulnerability of ice wedges to thermokarst strongly depends on the thickness and properties of soil layers overlying ice wedges (Kanevskiy et al. 2017), which include active, transient, and intermediate layers (Shur 1988; Shur et al. 2005; French and Shur 2010; Shur et al. 2011). For estimation of vulnerability, we consider the three protective layers (PL) of frozen soils (Fig. 4A): PL1 (a total thickness of frozen soil above the ice wedge, which includes the frozen part of the active layer, the transient layer, and the intermediate layer); PL2 (includes transient and intermediate layers), and PL3 (ice-rich intermediate layer, which provides a long-term protection for the ice wedges and may be detected based on the analysis of cryostructures).

Our system of evaluation of vulnerability of ice wedges to thermokarst (Fig. 4B) is based on measured thicknesses of these protective layers. Accuracy of evaluation strongly depends on time of field studies because PL1 thickness constantly decreases during the thawing season, and at some point PL2 and PL3 may also experience thawing, which makes evaluation of ice-wedge vulnerability very complex. To address this problem, we suggest estimating vulnerability levels based on measurements of protective layers PL1, PL2, and PL3, which may be performed during two time periods: late July to mid-August (when the active layer is still thawing) and late August to mid-September (when the active layer is close to its maximal thickness for the current year). If field studies are performed before mid-July, such evaluation cannot be accurate, and only the thickness of PL3 (intermediate layer) can be taken into consideration. 
Table 1. Main stages of the ice-wedge degradation and stabilization (see Fig.1) and their characteristics for the Prudhoe Bay area, modified from Kanevskiy et al. (2017). JS, Jorgenson Site.

\begin{tabular}{|c|c|c|c|c|c|c|}
\hline Stage & $\begin{array}{l}\text { Duration } \\
\text { (years) }\end{array}$ & $\begin{array}{l}\text { Water } \\
(\mathrm{cm})\end{array}$ & Ice wedges (IW) & $\begin{array}{l}\text { Intermediate layer (IL), } \\
\text { typical thickness at JS }\end{array}$ & Thermokarst-cave ice (TCI) & Vegetation \\
\hline $\begin{array}{l}\text { UD - undisturbed } \\
\text { ice wedges }\end{array}$ & Variable & 0 & Undisturbed ice wedges & Undisturbed, 5-20 cm & $\begin{array}{l}\text { Relict TCI bodies occasionally } \\
\text { occur (formed during previous } \\
\text { degradation events) }\end{array}$ & Dwarf shrubs \\
\hline $\begin{array}{l}\text { D1 - initial } \\
\quad \text { degradation (DI) }\end{array}$ & $<10$ & $<10$ & $\begin{array}{l}\text { Ice wedges melt with thaw } \\
\text { subsidence up to } \\
20-30 \mathrm{~cm} \text {; wedges } \\
\text { continue growing } \\
\text { laterally }\end{array}$ & Total degradation & $\begin{array}{l}\text { Partial degradation of relict TCI } \\
\text { bodies }\end{array}$ & $\begin{array}{l}\text { Dwarf shrubs, } \\
\text { sedges }\end{array}$ \\
\hline $\begin{array}{l}\mathrm{D} 2 \text { - advanced } \\
\text { degradation (DA) }\end{array}$ & $<10-10$ s & $10 \mathrm{~s}$ & $\begin{array}{l}\text { Degradation with thaw } \\
\text { subsidence up to } 100 \mathrm{~cm}\end{array}$ & Total degradation & $\begin{array}{l}\text { Small cavities on top of ice } \\
\text { wedges filled with water; } \\
\text { partial or total degradation of } \\
\text { relict TCI bodies }\end{array}$ & $\begin{array}{l}\text { Calcareous aquatic } \\
\text { mosses, forbs }\end{array}$ \\
\hline $\begin{array}{l}\text { SI1- initial } \\
\quad \text { stabilization (1) }\end{array}$ & $<10$ & 0 & $\begin{array}{l}\text { Wedges continue growing } \\
\text { laterally }\end{array}$ & Initial recovery $0-5 \mathrm{~cm}$ & $\begin{array}{l}\text { Relict TCI bodies may occur } \\
\text { (formed during a previous } \\
\text { degradation cycle) }\end{array}$ & $\begin{array}{l}\text { Dwarf shrubs, } \\
\text { sedges }\end{array}$ \\
\hline $\begin{array}{l}\text { SI2 - initial } \\
\quad \text { stabilization (2) }\end{array}$ & $<10-10$ s & 0 to $10 \mathrm{~s}$ & $\begin{array}{l}\text { Formation of IW is possible } \\
\text { if the water depth is less } \\
\text { than } 20-30 \mathrm{~cm}\end{array}$ & $\begin{array}{l}\text { Initial recovery } \\
0-10 \mathrm{~cm}\end{array}$ & $\begin{array}{l}\text { Relatively small TCI bodies may } \\
\text { form }\end{array}$ & Aquatic sedges \\
\hline $\begin{array}{l}\text { SA1 - advanced } \\
\quad \text { stabilization (1) }\end{array}$ & $<10-10$ s & 0 & $\begin{array}{l}\text { Wedges continue growing } \\
\text { laterally and vertically (in } \\
\text { the recovering IL) }\end{array}$ & Recovery 5-15 cm & $\begin{array}{l}\text { Relict TCI bodies may occur } \\
\text { (formed during a previous } \\
\text { degradation cycle) }\end{array}$ & $\begin{array}{l}\text { Dwarf shrubs, } \\
\text { sedges }\end{array}$ \\
\hline $\begin{array}{l}\text { SA2 - advanced } \\
\quad \text { stabilization (2) }\end{array}$ & $10 s-100 s$ & 0 & $\begin{array}{l}\text { Formation of young IW } \\
\text { within IL and (or) TCI }\end{array}$ & Recovery 5-50 cm & $\begin{array}{l}\text { Preservation of TCI bodies under } \\
\text { the developing IL }\end{array}$ & Sedges \\
\hline
\end{tabular}


Fig. 4. Estimation of vulnerability of ice wedges to thermokarst. (A) Protective layers of frozen soils preventing wedge ice from thawing; (B) evaluation of vulnerability of ice wedges to thermokarst for northern Alaska based on measurements of thicknesses of protective layers during field studies performed after late July (modified from Kanevskiy et al. 2016, 2017).

A

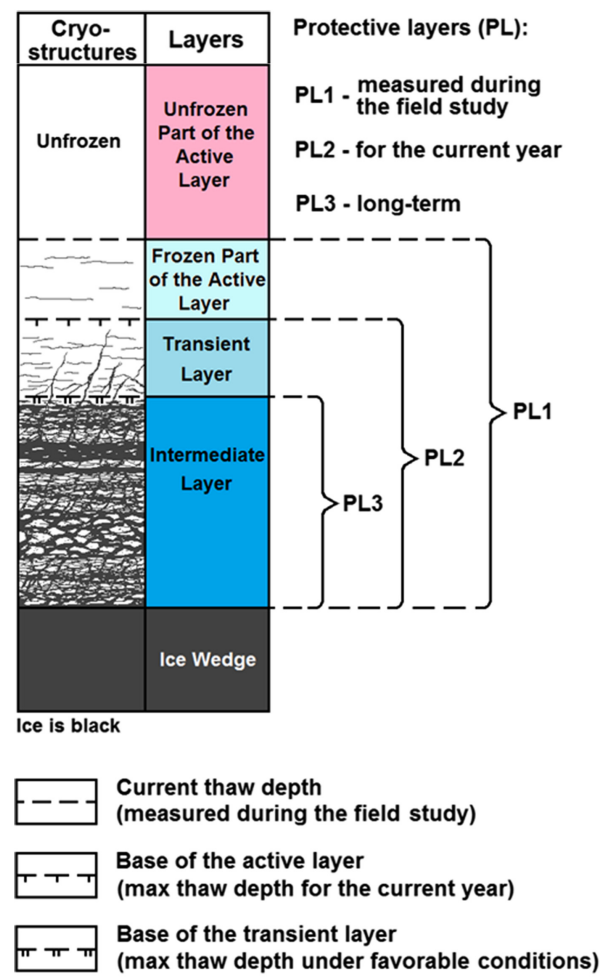

B

\begin{tabular}{|c|c|c|c|c|}
\hline \multirow{2}{*}{$\begin{array}{c}\text { Vulnerability } \\
\text { level }\end{array}$} & \multicolumn{3}{|c|}{$\begin{array}{l}\text { Thickness of } \\
\text { protective layers, cm }\end{array}$} & \multirow[t]{2}{*}{ Notes } \\
\hline & \begin{tabular}{|l|} 
PL1 $^{*}$ \\
\end{tabular} & PL2*ᄎ & $\mathrm{PL3}^{*}$ & \\
\hline $\begin{array}{l}\text { 1. Active } \\
\text { degradation }\end{array}$ & 0 & 0 & 0 & $\begin{array}{l}\text { No protective layers; the top part of the ice wedge is } \\
\text { currently*degrading; degradation of the ice wedge of } \\
\text { up to } 5 \mathrm{~cm} \text { is expected by the end of warm season }\end{array}$ \\
\hline \multirow[b]{2}{*}{ 2. Very high } & $1-5$ & 0 & 0 & $\begin{array}{l}\text { Degradation of the top part of the ice wedge is } \\
\text { expected by the end of warm season }\end{array}$ \\
\hline & $=\mathrm{PL} 3$ & 0 & $1-5$ & $\begin{array}{l}\text { Thin intermediate layer is currently }{ }^{\star} \text { degrading; } \\
\text { degradation of the top part of the ice wedge is } \\
\text { expected by the end of warm season }\end{array}$ \\
\hline \multirow{3}{*}{ 3. High } & $5-10$ & $1-5$ & 0 & $\begin{array}{l}\text { No intermediate layer, thin degrading transient layer; } \\
\text { minor degradation of some parts of this ice wedge is } \\
\text { possible by the end of warm season }\end{array}$ \\
\hline & $5-10$ & $1-5$ & $1-5$ & $\begin{array}{l}\text { Partial degradation of the intermediate layer is } \\
\text { expected by the end of warm season; } \\
\text { minor degradation of some parts of this ice wedge is } \\
\text { possible by the end of warm season }\end{array}$ \\
\hline & $=P L 3$ & $1-5$ & $5-10$ & $\begin{array}{l}\text { Intermediate layer is currently* degrading; } \\
\text { minor degradation of some parts of this ice wedge is } \\
\text { possible by the end of warm season }\end{array}$ \\
\hline \multirow{3}{*}{ 4. Moderate } & $10-20$ & $5-15$ & $1-5$ & $\begin{array}{l}\text { No significant degradation of the intermediate layer } \\
\text { and no ice-wedge degradation are expected during } \\
\text { the current year }\end{array}$ \\
\hline & $10-20$ & 5-15 & $5-10$ & $\begin{array}{l}\text { Partial degradation of the intermediate layer is } \\
\text { possible by the end of warm season; no ice-wedge } \\
\text { degradation is expected during the current year }\end{array}$ \\
\hline & $=P L 3$ & $5-15$ & $10-20$ & $\begin{array}{l}\text { Relatively thick intermediate layer is currently }{ }^{*} \\
\text { degrading; no ice-wedge degradation is expected } \\
\text { during the current year }\end{array}$ \\
\hline \multirow{3}{*}{ 5. Low } & $20-30$ & $15-25$ & 5-10 & $\begin{array}{l}\text { No degradation of the intermediate layer is expected } \\
\text { during the current year }\end{array}$ \\
\hline & $20-30$ & $15-25$ & $10-20$ & $\begin{array}{l}\text { No significant degradation of the relatively thick } \\
\text { intermediate layer is expected during the current year }\end{array}$ \\
\hline & \begin{tabular}{|l|}
$=$ PL3 \\
\end{tabular} & $>15$ & $>20$ & Thick intermediate layer is currently ${ }^{*}$ degrading \\
\hline 6. Very low & $\begin{array}{l}>30 \\
>\mathrm{PL} 3\end{array}$ & $\begin{array}{l}>25 \\
>\text { PL3 }\end{array}$ & $>20$ & $\begin{array}{l}\text { The ice wedge is well protected by thick and stable } \\
\text { intermediate layer; ice-wedge degradation is possible } \\
\text { only due to a strong impact on the surface (flooding, } \\
\text { vegetation removal) or after accumulation of wedge } \\
\text { ice within the intermediate layer }\end{array}$ \\
\hline
\end{tabular}

The color-coded system of evaluation of vulnerability of ice wedges (Fig. 4B) includes six levels, from bright red (vulnerability level 1, the highest) to dark green (vulnerability level 6 , the lowest) (Kanevskiy et al. 2016, 2017). The two highest vulnerability levels are related to currently degrading wedges. The difference between them is determined by the activity of degradation: although the first vulnerability level refers to active degradation with significant thawing of ice wedges, the second level corresponds to slow degradation, when the depth of seasonal thawing can reach the top surface of ice wedges only at the end of the warm season. The third vulnerability level is related to ice wedges, which are not currently degrading, but the protective layer is so thin that degradation can start very easily, and some parts of the studied wedges that belong to this category may already have undergone degradation at the time of this study. Vulnerability levels from four to six represent ice wedges currently protected from thawing; the thickest protective layers are attributed to the sixth level. For studies performed before mid-July, vulnerability levels may be estimated only approximately, based solely on thicknesses of the intermediate layer (that may be detected based on the analysis of cryostructures): PL3 $=0 \mathrm{~cm}$ - levels 1 to 2 (active degradation or very high vulnerability); 1 to $5 \mathrm{~cm}$ - level 3 (high vulnerability); 5 to $10 \mathrm{~cm}$ - level 4 (moderate vulnerability); 10 to $20 \mathrm{~cm}$ - level 5 (low vulnerability); and PL3 $>20 \mathrm{~cm}-$ level 6 (very low vulnerability). 


\section{Results}

Frozen soil and ground ice

Relatively undisturbed area: Jorgenson Site (JS)

In the JS, the structure and properties of frozen soils and ground ice were studied at 113 boreholes up to $3.5 \mathrm{~m}$ deep (Jorgenson et al. 2015; Kanevskiy et al. 2017). Three boreholes drilled in the polygon centers (Fig. $S 4^{2}$ ) showed that the upper permafrost was composed mostly of organic silts with peat inclusions, which we interpret as a shallow lake deposit (Jorgenson et al. 2015; Kanevskiy et al. 2017). Massive ground ice (wedge ice and TCI) was encountered in 83 of $113(73.4 \%)$ boreholes (Table S1 ${ }^{2}$ ). Profiles across and along ice-wedge troughs (Figs. S5, S6, and $\mathrm{S7}^{2}$ ) reveal that wedges varied from 1.5 to $3.5 \mathrm{~m}$ in width, and their vertical extent was $\sim 3 \mathrm{~m}$. Mean ice-wedge volume in the upper $3 \mathrm{~m}$ of permafrost (as \% of layer volume) was $21.5 \pm 6.3 \%$ ( \pm SD) (Jorgenson et al. 2015). Thermokarst-cave ice occurred in $26.5 \%$ of boreholes (Table $\mathrm{S1}^{2}$ ), more often within or adjacent to ice wedges at various stages of stabilization. We presumed that most of ice wedges in the study area were active, which was confirmed by occurrence of young ice wedges that had developed in recently formed TCI bodies (e.g., Fig. S6 ${ }^{2}$, profiles DI2 and SA2).

In many cases, massive-ice bodies were protected by a frozen intermediate layer (PL3) up to $84 \mathrm{~cm}$ thick, with the average thickness $8.6 \mathrm{~cm}(n=83)$ (Table 2, Table $\left.S 1^{2}\right)$. In more than $45 \%$ of boreholes, the IL thickness was less than $1 \mathrm{~cm}$ (Fig. 5A) (Kanevskiy et al. 2017). Thickness of PL1 (including the frozen part of the active layer, transient layer, and intermediate layer) was estimated only for boreholes drilled in July 2012; PL1 thickness at that time varied from 3 to $88 \mathrm{~cm}$ (no ice wedges experienced thawing during the field work) with the average value of $17.7 \mathrm{~cm}(n=39)$ (Table 2, Table $\left.S 1^{2}\right)$. An average seasonal thaw depth in July 2012 was $42.2 \mathrm{~cm}(n=39)$ and varied from $33.6 \mathrm{~cm}(\mathrm{DI}, n=5)$ to $\sim 45 \mathrm{~cm}$ (SI and SA), depending on stage of degradation/stabilization (Table $S 1^{2}$ ).

Areas affected by development: Colleen Site (CS) and Airport Site (AS)

At the CS, 57 boreholes were drilled in polygon centers and troughs in August 2014, and one in March 2016 (Walker et al. 2015, 2018) (Fig. 3A). Analysis of cryostructures of 12 cores obtained in polygon centers showed that the current thaw depth (measured during the period August 7 to 12 , Table $S 2^{2}$ ) was commonly 6 to $12 \mathrm{~cm}$ less than the total thickness of the active and transient layers, which represent potential seasonal thawing under favorable conditions (high summer temperatures in combination with high moisture). The upper permafrost in sections of all these boreholes was composed of organic and organic-mineral soils. Depth to organic-poor mineral soils (silts, sands, or gravelly sands) of presumably alluvial and eolian origin usually varied from 1.2 to $2.0 \mathrm{~m}$. Based on the drilling in polygon centers, five cryostratigraphic units were detected (Table S2 ${ }^{2}$ ). Photographs of the frozen soils from these boreholes are presented in Fig. $\mathrm{Ss}^{2}$.

Information on the boreholes drilled in ice-wedge troughs and on adjacent rims of polygons is presented in Table $\mathrm{S}^{2}$. We drilled at 13 sites along T1 and 9 sites along T2. At some sites, several boreholes (up to nine) were drilled across ice-wedge troughs to determine ice-wedge widths and morphology of their upper parts (Fig. 6). The total number of trough/rim boreholes was 44 (28 along T1 and 16 along T2); 36 of 44 boreholes ( 82\%) encountered massive ground ice: wedge ice (WI) and (or) thermokarst-cave ice (TCI), or composite (ice/soil) wedges (CW); TCI occurred in 8 of $36(\sim 22 \%)$ boreholes (Table S3 ${ }^{2}$ ). The deepest borehole drilled through the massive ice at the middle of the trough reached the gravel at $3 \mathrm{~m}$ (borehole T1-200T-1) (Fig. 6). A large complex TCI body was encountered in this trough (Fig. 6, profile T1-200); it was dissected by frost cracks and contained a young ice wedge, which suggests that the ice wedge resumed its development after formation of the TCI body. 
Table 2. Average thicknesses of frozen protective layers above massive-ice bodies in boreholes drilled in ice-wedge troughs, Prudhoe Bay transects.

\begin{tabular}{|c|c|c|c|c|c|c|}
\hline Transect & $\begin{array}{l}\text { Thaw } \\
\operatorname{depth}^{a}(\mathrm{~cm})\end{array}$ & $\begin{array}{l}\text { Permafrost } \\
\text { table }^{b}(\mathrm{~cm})\end{array}$ & $\begin{array}{l}\text { Depth to } \\
\text { massive ice }(\mathrm{cm})\end{array}$ & $\begin{array}{l}\text { Frozen protective } \\
\text { layer }(\mathrm{PL} 1 / \mathrm{PL} 2)^{c}(\mathrm{~cm})\end{array}$ & $\begin{array}{l}\text { Intermediate } \\
\text { layer (PL3) }(\mathrm{cm})\end{array}$ & $\begin{array}{l}\text { Actively degrading } \\
\text { ice wedges }{ }^{d}(\%)\end{array}$ \\
\hline \multicolumn{7}{|l|}{ Relatively undisturbed area } \\
\hline JS, 9-14 June 2011; 22-27 July 2012 & $42.2(n=39)$ & $47.5(n=83)$ & $56.0(n=83)$ & 17.7 (PL1) $(n=39)$ & $8.6(n=83)$ & $0(n=39)$ \\
\hline \multicolumn{7}{|l|}{ Areas affected by development } \\
\hline $\begin{array}{l}\text { CS, transect T1, 7-14 August 2014; } \\
29 \text { March } 2016\end{array}$ & $40.9(n=22)$ & $48.7(n=23)$ & $50.6(n=23)$ & $8.1(\mathrm{PL} 1)(n=22)$ & $1.9(n=23)$ & $9.1(n=22)$ \\
\hline CS, transect T2 (wet), 10-13 August 2014 & $49.2(n=13)$ & $55.2(n=13)$ & $60.2(n=13)$ & 11.1 (PL1) $(n=13)$ & $5.0(n=13)$ & $0(n=13)$ \\
\hline $\begin{array}{l}\text { AS, transect T3, 18-22 September } 2015 \\
\text { (PL1 = PL2) }\end{array}$ & $54.7(n=12)$ & $55.0(n=12)$ & $57.0(n=12)$ & 2.3 (PL2) $(n=12)$ & $2.0(n=12)$ & $50.0(n=12)$ \\
\hline $\begin{array}{l}\text { AS, transect T5 (wet), 20-21 September } 2015 \\
\text { (PL1 = PL2); } 28 \text { March } 2016\end{array}$ & $53.4(n=12)$ & $54.1(n=14)$ & $61.3(n=14)$ & 9.3 (PL2) $(n=12)$ & $7.2(n=14)$ & $9.2(n=12)$ \\
\hline
\end{tabular}

Note: JS, Jorgenson Site; CS, Colleen Site; and AS, Airport Site.

${ }^{a}$ Measurements of thaw depth performed in June 2011 (JS) and March 2016 (CS, T1 and AS, T5) were excluded from the calculations.

${ }^{b}$ Top of the intermediate layer (based on the analysis of cryostructures) or massive-ice body (at locations with degrading ice wedges).

${ }^{\circ}$ Thickness of frozen soil layer on top of massive-ice bodies on the day of drilling; PL1 includes the frozen part of the active layer, transient layer, and intermediate layer; PL2 includes the transient and intermediate layers (in September, PL1 = PL2); results of drilling in June 2011 (JS) and March 2016 (CS, T1 and AS, T5) were excluded from the calculations.

${ }^{d}$ Percent of boreholes drilled between late July and mid-September, which encountered ice wedges actively degrading on the day of drilling (PL1 $=0$ ). 
Fig. 5. Thicknesses of the intermediate layer (PL3) across all cores that encountered massive-ice bodies (wedge ice and (or) thermokarst-cave ice). (A) based on the data from the three study sites in the Prudhoe Bay area (JS - June 2011, July 2012; CS (T1+T2) - August 2014, March 2016; AS (T3+T5) - September 2015, March 2016); (B) based on the data from the "dry" undisturbed JS; "dry" T1 (CS) and T3 (AS) transects; and "wet" T2 (CS) and T5 (AS) transects affected by flooding events.

A

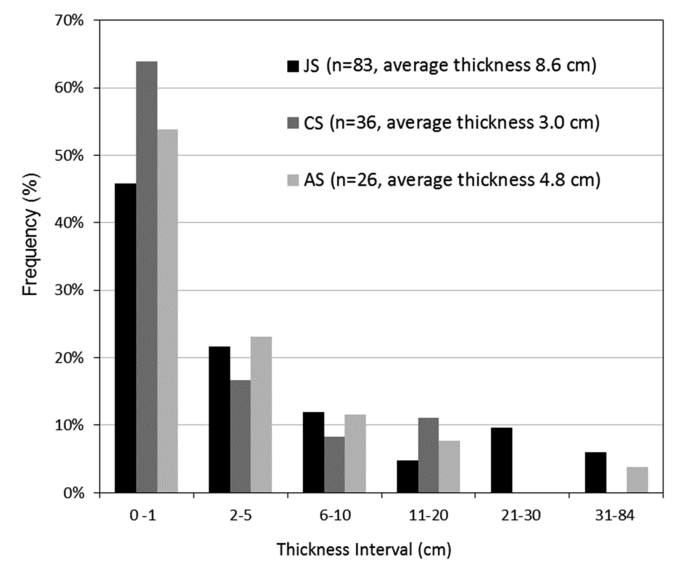

$\mathrm{B}$

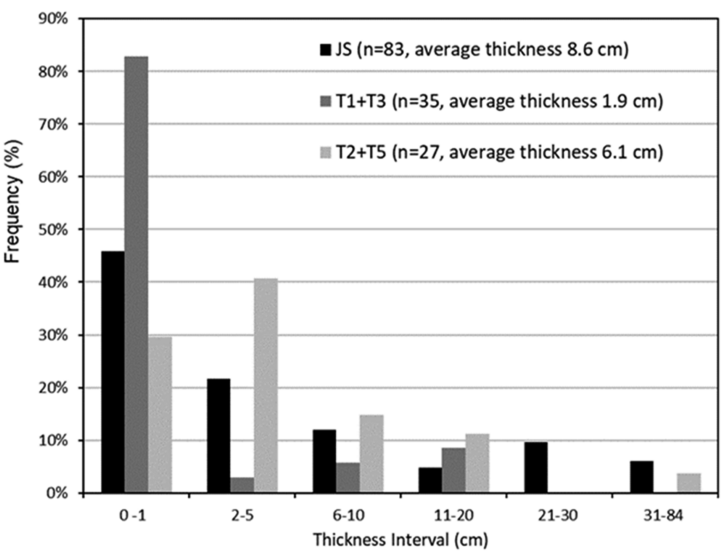

In August 2014, ice wedges, which were thawing at the time of drilling, were found only in two of 35 boreholes, both of them at T1 ( 9\% of boreholes of this transect). The thaw depth at this time varied from 27 to $68 \mathrm{~cm}$ (average values were $40.9 \mathrm{~cm}$ for T1 and $49.2 \mathrm{~cm}$ for T2, and $44.0 \mathrm{~cm}$ for boreholes of both transects) (Table 2 and Table S3 ${ }^{2}$ ). In many cases, massive-ice bodies were protected by a frozen intermediate layer (PL3) up to $19 \mathrm{~cm}$ thick, with an average thickness of $3.0 \mathrm{~cm}$ (Table 2 and Table S3 ${ }^{2}$, Fig. 5A). In almost 65\% of boreholes, the IL thickness was less than $1 \mathrm{~cm}$ (Fig. 5A). For T1, the average thickness of PL1 (includes the frozen part of the active layer, transient layer and (or) intermediate layer) was $8.1 \mathrm{~cm}$, and the average thickness of PL3 was $1.9 \mathrm{~cm}$. For T2, these thicknesses were $11.1 \mathrm{~cm}$ and $5.0 \mathrm{~cm}$, respectively. Thus, ice wedges at the T2 transect, which was strongly affected by seasonal flooding, had thicker protective layers and were better protected than at T1. Photographs of the frozen soils on top of wedge ice, including the ice-rich IL (PL3), are presented in Fig. $S 9^{2}$.

At the Airport Site (AS), 30 shallow boreholes were drilled along $100 \mathrm{~m}$ transects T3 and T5 (Fig. 3B and C, Table S4 ${ }^{2}$ ); 28 of them were drilled during 18-23 September 2015, and two boreholes were drilled at T5 in the deep pond on 28 March 2016 (Walker et al. 2016, 2018). No boreholes were drilled along T4 because of extensive near-surface gravel from numerous previous roads. Deep water over most of the transect also made coring difficult. Due to severe weather conditions, the number of boreholes was smaller in comparison with the field study of 2014. Only two boreholes (one for each transect) were drilled in ice-wedge polygon centers (Fig. 7). Photographs of the frozen soils from these boreholes are presented in Fig. $S 10^{2}$. All other boreholes $(n=28)$ were drilled in polygon troughs along both transects at different distances from the Dalton Highway. Massive ground ice was found in 26 of 28 boreholes, including wedge ice (WI), thermokarst-cave ice (TCI), and composite (ice/soil) wedges (CW); TCI occurred in 5 of $26(\sim 19 \%)$ boreholes (Table S4 $\left.{ }^{2}\right)$. Most of the boreholes were drilled in the central parts of dry or water-filled ice-wedge troughs. Several boreholes were drilled from the surface of low mounds or "ridges" located within the troughs (Fig. 8, T5-69.6 and T5-100.5). By the time of drilling (18 to 22 September), seasonal thaw depth 
Fig. 6. Cross-sections across and along ice-wedge troughs, Prudhoe Bay, Colleen Site (CS) (for location of profiles, see Fig. 3A). Notes: (1) No actively degrading ice wedges were detected at the time of coring (mid-August), although the ice wedge at the T1-25T profile had a protective layer (PL1) only 1 to $3 \mathrm{~cm}$ thick; (2) a thin intermediate layer was detected above the ice wedge at the T2-200T profile (marked as SS); (3) in the legend, AL unit includes unfrozen and frozen parts of the active layer and frozen transient layer.
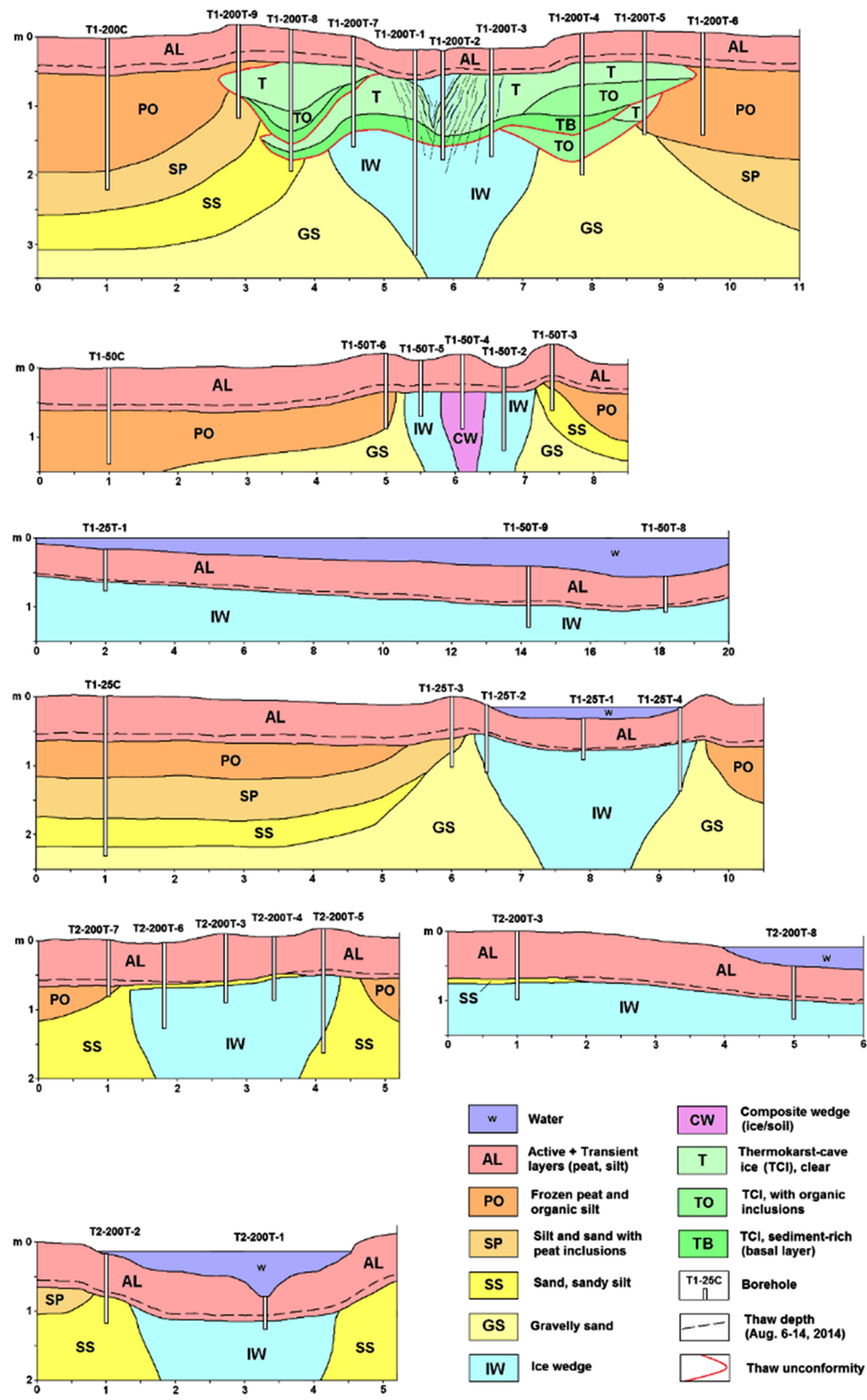

- Published by Canadian Science Publishing 
Fig. 7. Cryostratigraphy and moisture contents of the upper permafrost, Airport Site (AS) (for locations, see Fig. 3B and C). Cryostratigraphic units: (1) Unfrozen active layer (silty peat with layers of organic silt); (2) frozen transient layer (organic silt, ice-poor); (3) perennially-frozen organic- and ice-rich silt with peat inclusions; (4) perenniallyfrozen organic- and ice-rich silt.

T3-59.0-C

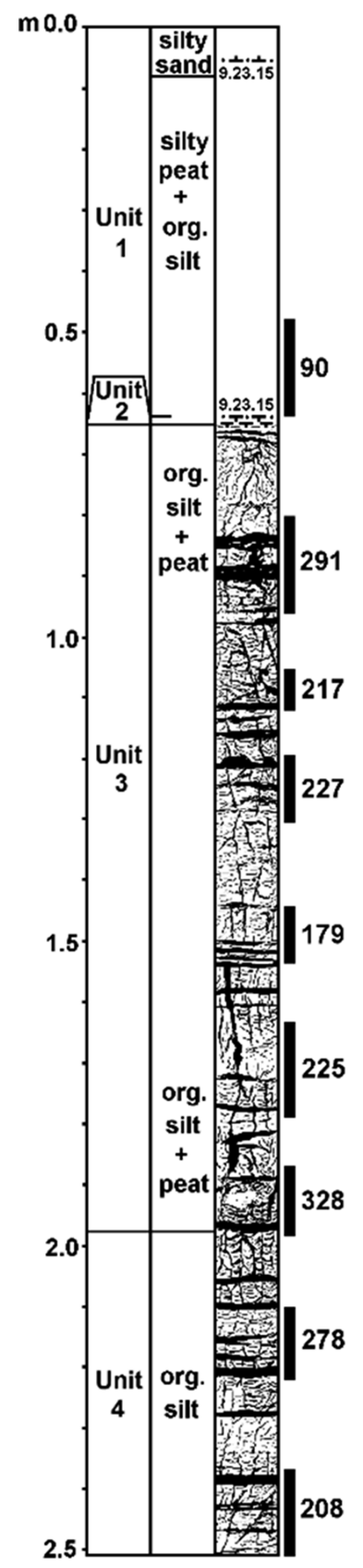

T5-65.4-C

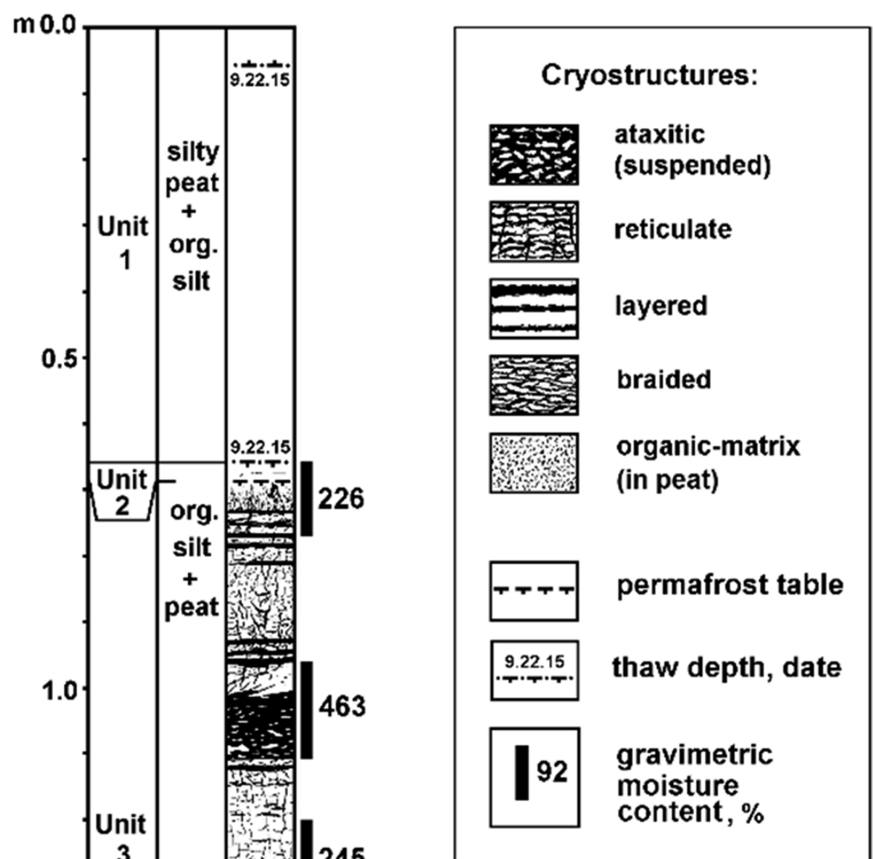


Fig. 8. Cross-sections across and along ice-wedge troughs, Prudhoe Bay, Airport Site (AS) (for location of profiles, see Fig. 3B and C). Notes: (1) Actively degrading ice wedges at the time of coring (mid-September) were detected in boreholes T3-70.3, T5-93.0, and T5-94.5, whereas the ice wedges in boreholes T3-70.4, T3-84.1, T3-90.0, T5-40.3 had a protective transient layer (PL2) only 0.5 to $1 \mathrm{~cm}$ thick; (2) the ice-rich intermediate layer 1 to $65 \mathrm{~cm}$ thick was detected above the ice wedges in all other boreholes (marked as PO); (3) in the legend, AL unit includes unfrozen and frozen parts of the active layer and frozen transient layer; (4) boreholes T5-94.5 and T5-96.8 were drilled in March 2016.
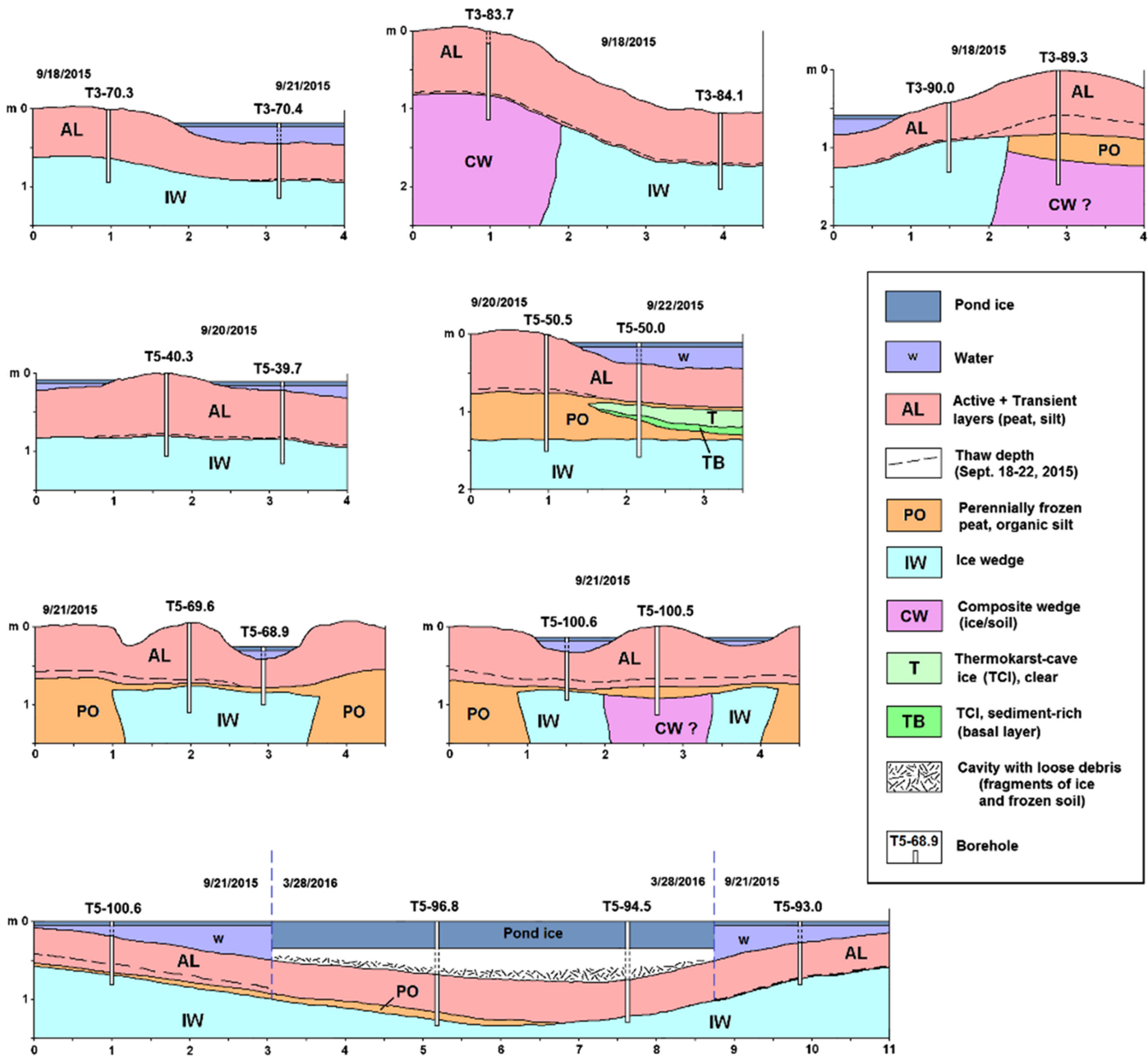

already reached its maximum (i.e., PL1 = PL2); the ALT varied from 36 to $69 \mathrm{~cm}$ (average values were $54.7 \mathrm{~cm}$ for T3, $53.4 \mathrm{~cm}$ for T5, and $54.0 \mathrm{~cm}$ for boreholes of both transects) (Table 2 and Table $S 4^{2}$ ).

At the time of drilling, a 0.5 - to 65-cm-thick protective layer of frozen soil, which includes the transient layer and (or) intermediate layer (PL2), was observed above the majority of ice wedges. The ice-rich intermediate layer (PL3) up to $61 \mathrm{~cm}$ thick was encountered in 12 boreholes (two at T3 and 10 at T5) the average thickness of the intermediate layer was $4.8 \mathrm{~cm}$ $\left(\right.$ Table $\mathrm{S}^{2}$ ). In almost $55 \%$ of boreholes the IL was either absent or $<1 \mathrm{~cm}$ thick, whereas in more than $20 \%$ of boreholes its thickness varied from 2 to $5 \mathrm{~cm}$ (Fig. 5A). Ice wedges at T5 were protected significantly better compared with those at T3. For T3, the average thickness 
of PL2 was $2.3 \mathrm{~cm}$, and the average thickness of PL3 was $2.0 \mathrm{~cm}$. For T5, these thicknesses were $9.3 \mathrm{~cm}$ and $7.2 \mathrm{~cm}$, respectively (Table 2 and Table S4 $4^{2}$ ). One of the reasons these numbers were so high in comparison with $\mathrm{T} 3$ is the occurrence of just one site (T5-50.5) with exceptionally thick protective layers (PL1 $=65 \mathrm{~cm}$, PL3 $=61 \mathrm{~cm}$ ), associated with a previous cycle of deep ice-wedge degradation and subsequent stabilization that could have occurred centuries ago; without this site, the average T5 values for PL1 and PL3 would be significantly lower -4.2 and $3.1 \mathrm{~cm}$, respectively - but still significantly higher than T3 values. Photographs of the frozen soils on top of wedge ice, including the ice-rich IL, are presented in Fig. S11 ${ }^{2}$.

\section{Climatic and environmental factors}

Relatively undisturbed area: Jorgenson site (JS)

Climatic and environmental factors at the JS were described and analyzed by Jorgenson et al. (2015). Annual mean air temperature measured at the JS transect at $1.5 \mathrm{~m}$ above the ground surface during 2012 hydrologic year (September 2011 to August 2012) was $-10.6{ }^{\circ} \mathrm{C}$ (Jorgenson et al. 2015). Annual mean surface temperatures measured along the transect during 2012 varied significantly among degradation stages: from $-6.2{ }^{\circ} \mathrm{C}$ (UD) to $-1.3^{\circ} \mathrm{C}$ (DA). Annual mean ground temperature measured at $50 \mathrm{~cm}$ below the surface (near the permafrost table) had similar trends, ranging from $-7.3{ }^{\circ} \mathrm{C}(\mathrm{UD})$ to $-3.5^{\circ} \mathrm{C}(\mathrm{DA})$ (Jorgenson et al. 2015). In a location just south of the study area (Deadhorse site, $70.161283^{\circ} \mathrm{N}$, $148.4653^{\circ} \mathrm{W}$ ), MAGT measured at the depth of $20 \mathrm{~m}$ has increased during the last decades from $-8.7^{\circ} \mathrm{C}(1978)$ to $-5.6{ }^{\circ} \mathrm{C}(2016)$, with a rapid increase since 1993 (Romanovsky et al. $2016,2017)$. The data from vegetation surveys at the JS were presented by Jorgenson et al. (2015).

Microtopography in the JS was characterized by abundant thermokarst troughs on top of degrading ice wedges (Fig. S12 ${ }^{2}$ ), some of them filled with water. We describe ice-wedge polygons at this area as transitional from low-centered to high-centered because most of polygons had well developed elevated rims, but their troughs were usually lower than the polygon centers; high- and low-centered polygons were also observed in this area, but they were not dominant. The maximum depths of the larger troughs associated with the DA stage tended to be 0.5 to $0.9 \mathrm{~m}$ below the adjacent polygon centers (water depths varied from 0.3 to $0.5 \mathrm{~m}$ ), the widths of these troughs at the top varied from 1 to $4 \mathrm{~m}$, and the tops of the polygons were 8 to $15 \mathrm{~m}$ across. Surface water was commonly impounded in thermokarst troughs and pits as indicated by the topographic profile (Fig. S12 ${ }^{2}$ ). Jorgenson et al. (2015) manually delineated thermokarst troughs around the JS transect using air photos (time series of eight images from 1949 to 2012) and found that the area occupied by waterfilled troughs increased from $0.9 \%$ to $7.5 \%$ over this period. They attributed the ice-wedge degradation to extremely warm and wet summers in 1989 and 1998.

Average snow depth measured on 8 May 2012, was $35.7 \mathrm{~cm}$ (Table S5 ${ }^{2}$ ). Snow depths were significantly different among stages, with mean snow depths much deeper at DA sites $(52.2 \mathrm{~cm})$ compared with UD $(31.8 \mathrm{~cm})$ (Jorgenson et al. 2015). Very shallow snow depths (less than $15 \mathrm{~cm}$ at some places) were measured within polygon centers and especially on elevated rims of polygons (Fig. S12 ${ }^{2}$ ). Average snow depth measured along this transect on 29 March 2016, was $30.0 \mathrm{~cm}$ (Table S5ㄹ), varying from 12 to $57 \mathrm{~cm}$.

Measurements of seasonal thaw at the JS were performed several times since 2012, mainly in August and September; average values in 2012-2016 varied from 50 to $59 \mathrm{~cm}$ (Table $\mathrm{S}^{2}$, Fig. S13 ${ }^{2}$ ). For comparison, average active-layer thicknesses measured at the Deadhorse CALM site U6 in 2012-2016 showed much smaller variations - between 69 and $73 \mathrm{~cm}$ (Fig. S1 ${ }^{2}$ ). Measurements taken at the JS from late August to mid-September revealed relatively small interannual differences in the ALT: mean thaw depths were $56.2 \mathrm{~cm}$ on 
29 August 2012, $59.0 \mathrm{~cm}$ on 2 September 2013, and $58.7 \mathrm{~cm}$ on 16 September 2015. Increase in thaw depth measured between 7 August and 16 September 2015, was less than $2 \mathrm{~cm}$ (Table $\mathrm{S6}^{2}$ ), but measurements performed in 2012 revealed a very significant (almost $13 \mathrm{~cm}$ ) increase in thaw depth between 26 July and 29 August. Comparison of average thaw depths measured on 11 August 2014, 7 August 2015, and 16 August 2016, showed that thaw depth in 2014 (very cold summer) was $\sim 7 \mathrm{~cm}$ less than in 2015 and almost $8 \mathrm{~cm}$ less than in 2016 (Fig. S132).

Areas affected by development: Colleen Site (CS) and Airport Site (AS)

Climatic and environmental factors at the CS were described and analyzed by Walker et al. (2018, 2022). Annual mean air temperatures at the CS (measured from July 2015 to July 2016 at 1.0 and $1.5 \mathrm{~m}$ above the ground surface at permanent plots along T1 and T2, at various distances from the road) varied from -7.6 to $-8.4{ }^{\circ} \mathrm{C}$ and did not correlate with the distance from the road (Walker et al. 2018). Average snow depths measured on 28 March 28 2016, were 34.5 for T1 and 42.3 for T2 (Table S5 ${ }^{2}$ ); the latter was much wetter and was characterized by larger and deeper troughs. Similar to JS and AS, snow depths were deepest in ice-wedge troughs and shallowest in the centers of polygons (Table $S 5 a^{2}$ ). Snowdrifts that formed on both sides of the road were mainly limited to within $25 \mathrm{~m}$ from the road. Snow was deeper, denser, and dirtier near the roads. Maximum snow depth was $80 \mathrm{~cm}$ in the roadside drift along $\mathrm{T} 1$ (windward side of the road) and $110 \mathrm{~cm}$ along T2 (leeward side) (Walker et al. 2018).

Annual mean surface and ground temperatures, which were measured at the same plots during the same time period, strongly depended on location (polygon center or ice-wedge trough) and distances from the road. Annual mean surface temperatures at both transects were approximately $1.3^{\circ} \mathrm{C}$ colder in polygon centers than in polygon troughs. Warmer temperatures corresponded to deeper trough depths, most likely due to deeper winter snow in the deeper troughs. Annual mean surface temperatures were significantly warmer on the wetter transect T2 (varied from -1.2 to $-4.1^{\circ} \mathrm{C}$ in centers and -1.1 to $-3.4^{\circ} \mathrm{C}$ in troughs) than on the drier transect $\mathrm{T} 1\left(-3.9\right.$ to $-4.5^{\circ} \mathrm{C}$ in centers and -2.2 to $-3.4{ }^{\circ} \mathrm{C}$ in troughs); the warmest temperatures were measured in ice-wedge troughs located close to the road (Walker et al. 2018). Similar trends were observed for annual mean ground temperatures measured at a depth of $40 \mathrm{~cm}$ below the surface (Table $\mathrm{S7}^{2}$ ).

At the CS area, microtopography was characterized by the common occurrence of ice-wedge polygons with deep water-filled troughs (Fig. 3A, Figs. S14, S15 ${ }^{2}$ ) (Walker et al. 2015, Buchhorn et al. 2016). Microtopography at T1 was similar to that of the JS, and most of polygons were transitional from low-centered to high-centered. Polygons at T2 commonly did not have well-developed rims, probably because this area was subjected to annual flooding events that resulted in faster destruction of elevated rims.

Within about $50 \mathrm{~m}$ of the road, soil surface horizons on both sides of the road were composed largely of road dust and gravel overlying the pre-development organic soil horizons. At $5 \mathrm{~m}$ from the road, these layers of dust were $18 \mathrm{~cm}$ thick at $\mathrm{T} 2$ and $10 \mathrm{~cm}$ thick at T1 (Walker et al. 2015). The data from the vegetation surveys along the CS transects are presented in the data reports (Walker et al. 2014, 2015). The changes at CS vegetation are described most thoroughly by Walker et al. (2022).

Average thaw depths in 2014-2016 varied from 48 to $58 \mathrm{~cm}$ for T1 and from 58 to $64 \mathrm{~cm}$ for T2 (Table $\mathrm{S6}^{2}$, Fig. $\mathrm{S}^{2} 3^{2}$ ). At permanent plots, average thaw depths (measured on 16 August 2016) in troughs were $51.8 \mathrm{~cm}$ at $\mathrm{T} 1$ and $57.3 \mathrm{~cm}$ at T2, whereas in polygon centers they were $60.6 \mathrm{~cm}$ at T1 and $60.5 \mathrm{~cm}$ at T2 (Table $S 6 a^{2}$ ).

Annual mean air temperatures at the Airport Site (AS) (measured from July 2015 to July 2016 at 1.0 and $1.5 \mathrm{~m}$ above ground at permanent plots along T3 and T4, at various 
distances from the road; no data for T5) varied from $-7.9{ }^{\circ} \mathrm{C}$ to $-8.6{ }^{\circ} \mathrm{C}$, which is very similar to the CS data (Walker et al. 2018). Annual mean surface and ground temperatures, which were measured for the same time period, were significantly colder in polygon centers than in polygon troughs; warmer temperatures corresponded to deeper trough depths (trends similar to those of the CS study area) (Table $S 7^{2}$ ).

Average snow depths measured on 28 March 2016 were $31.7 \mathrm{~cm}$ for T3 and $46.8 \mathrm{~cm}$ for T4; there are no data for T5 (Table $5^{2}$ ). Maximum snow depth was $77 \mathrm{~cm}$ in the roadside drift along T3 (windward side of the road) and $122 \mathrm{~cm}$ along T4 (leeward side). At permanent plots, the average snow depths in troughs were larger than in polygon centers (Table S5 $a^{2}$ ) (Walker et al. 2018).

At the AS, microtopography was characterized by the prevalence of ice-wedge polygons transitional from low-centered to high-centered, indicating past ice-wedge degradation. Similar to other study areas, most of polygons had elevated rims and deep troughs that were significantly lower than polygon centers (Fig. 3B and C). Most of the deep troughs at $\mathrm{T} 5$, which was poorly drained and had occasionally been affected by flooding events, were filled with water, whereas T3 was well drained by the Sagavanirktok River, and ponds could develop only in deepest parts of troughs. The data from vegetation surveys along the AS transects are presented in the data report (Walker et al. 2016).

Measurements of seasonal thaw performed on 17 September 2015, showed that the average ALT values at all three transects (T3, T4, and T5) were very close to each other: 63.6, 63.6, and $61.0 \mathrm{~cm}$, respectively (Table $\mathrm{S6}^{2}$ ). At permanent plots, the average thaw depths in polygon centers were larger than in troughs (Table S6 ${ }^{2}$ ) (Walker et al. 2018).

\section{Stages of ice-wedge degradation/stabilization and evaluation of vulnerability of ice wedges to thermokarst}

Characteristics of different stages of ice-wedge degradation/stabilization and estimated levels of vulnerability of ice wedges to thermokarst at the PBO study areas are summarized in Table 3. This table is based on the data presented in Tables S1, S3, and S4 ${ }^{2}$. Vulnerability levels were estimated according to the color-coded evaluation system based on average thicknesses of protective layers above massive-ice bodies (including ice wedges and TCI bodies) (Fig. 4). Within all three study areas, we did not find six of 13 ice-wedge degradation/ stabilization stages (Fig. 1, Table 1): D3, D4, SI3, SI4, SA3, and SA4. We also could not detect SA2 stage at the CS, and UD and SA1 stages at the AS (Table 3). In general, these stages (UD, SA1, and SA2) were very poorly represented at the CS and AS in comparison with the JS, which corresponds to more active ice-wedge degradation within the disturbed areas.

For the JS, which is characterized by relatively undisturbed conditions, overall vulnerability level was considered moderate with relatively thick protective layers (PL1 $=17.7 \mathrm{~cm}$, PL3 $=8.6 \mathrm{~cm}$ ), whereas ice wedges at the CS and AS, strongly affected by development, were much more vulnerable, and overall risk of further ice-wedge degradation for these transects was high (Tables 2 and 3, Fig. 5A).

At the CS, average thicknesses of protective layers for T1 were $8.1 \mathrm{~cm}$ (PL1) and $1.9 \mathrm{~cm}$ (PL3), which correspond to a high level of vulnerability of ice wedges to thermokarst. For $\mathrm{T} 2$, average thicknesses were $11.1 \mathrm{~cm}$ (PL1) and $5.0 \mathrm{~cm}$ (PL3), which correspond to moderate vulnerability level. Thus, the risk of degradation was much higher at T1, and two wedges that were degrading at the time of drilling were both located within T1.

At the AS, average thicknesses of protective layers for T3 were $2.3 \mathrm{~cm}$ (PL2) and $2.0 \mathrm{~cm}$ (PL3), which correspond to a high vulnerability level, whereas for T5 they were $9.3 \mathrm{~cm}$ (PL2) and $7.2 \mathrm{~cm}$ (PL3) (moderate level). The vulnerability of ice wedges to degradation was much higher at T3: in September 2015, only two of 12 boreholes (17\%) had protective frozen layers thicker than $1 \mathrm{~cm}$, which means that majority of ice wedges were either degrading or 
practically unprotected by the end of summer, whereas at $\mathrm{T} 5$ such layers were encountered in nine of 12 boreholes (75\%), and most of these nine wedges were protected by a thin intermediate layer (Table 2 and Table $S 4^{2}$ ).

Thus, the smallest thicknesses of the intermediate layer (PL3) were at relatively dry T1 (CS) and T3 (AS) transects (1.9 cm average, which corresponds to the high level of vulnerability of ice wedges to thermokarst). At "wet" T2 (CS) and T5 (AS) transects affected by flooding events, average thickness of the intermediate layer was $6.1 \mathrm{~cm}$, which corresponds to the moderate level. More than $80 \%$ of ice wedges at the "dry" T1 and T3 transects were not protected from thawing ( $\mathrm{IL}<1 \mathrm{~cm}$ ), in comparison with $\sim 45 \%$ at the JS, and $\sim 30 \%$ at the "wet" T2 and T5 transects (Fig. 5B).

The thickness of frozen protective layers and, therefore, levels of vulnerability of ice wedges to thermokarst in all study areas strongly depend on stages of ice-wedge degradation/stabilization: ice wedges at the UD, SA1, and SA2 stages were located deeper under the surface and relatively well protected by the intermediate layer (PL3), whereas most of the ice wedges at D1, D2, and SI1 stages had a very limited protection (Table 3, Fig. 9) and were either actively degrading or their vulnerability levels were high to very high (despite some surficial evidence of initial stabilization at SI sites).

\section{Discussion}

Impact of climatic and environmental factors on ice-wedge degradation and stabilization

Ice-wedge degradation in the study area, in most cases, has been triggered by an increase in the active-layer thickness during exceptionally warm and wet summers. Analysis of historical imagery showed that degradation of ice wedges at the JS started in the 1980s and significantly increased in the 1990 s (Fig. S16 ${ }^{2}$ ), likely after the very wet and warm summer of 1989; subsequent widespread thermokarst expansion may be attributed to extremely warm summers of 1998 and 2004 (Jorgenson et al. 2015) and 2012 (Walker et al. 2022).

Once initiated, degradation is controlled by numerous interacting factors such as vegetation, climate, topography, surface and groundwater, infrastructure development, and soil properties, which create positive and negative feedbacks to ice-wedge degradation (Jorgenson et al. 2006, 2010, 2015; Shur and Jorgenson 2007; Kanevskiy et al. 2017) (Table $\mathrm{S}^{2}$ ).

Vegetation is one of the most important environmental factors. Prior to discovery of the oilfield and development starting in 1968, the vegetation was similar at all three study sites (JS, CS, and AS). They all had similar low-centered ice-wedge polygons with less than $0.5 \mathrm{~m}$ of microrelief contrast between the centers and troughs (Everett 1980a), and the vegetation was typical of wetter portions of the Arctic Coastal Plain with base-rich non-acidic soils. Wet, non-acidic tundra vegetation dominated by sedges and mosses occupied lower microsites, such as polygon centers and troughs, and moist non-acidic tundra dominated by sedges, prostrate dwarf shrubs, mosses, and some lichens occurred on elevated microsites such as the polygon rims (Walker 1985; Walker and Everett 1991).

Vegetation changes since 1968 along the transects adjacent to the roads at CS and AS are primarily related to heavy road dust, roadside flooding, off-road vehicles, utility trenches, and thermokarst (Walker et al. 2022). The vegetation on the southwest sides of the road at both sites have become more productive due to flooding. The northeast sides of the road have experienced strong reductions in the diversity of small forbs, mosses, and lichens caused by the smothering effects of heavy road dust - the impacts of which affect a wide variety of other environmental factors that impact the permafrost, including the albedo of the vegetation and snow, timing of the snow melt, moss layer thickness, and active-layer thickness (Walker and Everett 1987; Walker et al. 2022). The documented circumpolar increase in shrubs due to the warming climate (Elemendorf et al. 2011; Myers-Smith et al. 2015; Bjorkman et al. 
Table 3. Average thicknesses of protective layers above massive-ice bodies and levels of vulnerability of ice wedges to thermokarst (level 1 corresponds to the highest vulnerability) at the three study sites in the Prudhoe Bay area, northern Alaska.

\begin{tabular}{|c|c|c|c|c|c|c|c|c|}
\hline Stage of degradation stabilization & $\begin{array}{l}\text { Number of } \\
\text { boreholes }(n)\end{array}$ & $\begin{array}{l}\text { Water } \\
\text { depth } \\
\text { (cm) }\end{array}$ & $\begin{array}{l}\text { Thaw } \\
\text { depth }^{a} \\
(\mathrm{~cm})\end{array}$ & $\begin{array}{l}\text { Perma-frost } \\
\text { table }^{b}(\mathrm{~cm})\end{array}$ & $\begin{array}{l}\text { Depth to } \\
\text { massive } \\
\text { ice }(\mathrm{cm})\end{array}$ & $\begin{array}{l}\text { Frozen protective } \\
\text { layer (PL1) }{ }^{a, c}(\mathrm{~cm})\end{array}$ & $\begin{array}{l}\text { Intermediate } \\
\text { layer (PL3) }(\mathrm{cm})\end{array}$ & $\begin{array}{l}\text { Vulnerability } \\
\text { level }\end{array}$ \\
\hline \multicolumn{9}{|c|}{ Relatively undisturbed area } \\
\hline Jorgenson Site (JS) & & & & & & & & \\
\hline Undisturbed wedges (UD) & 9 & - & {$[37.3(n=3)]$} & 43.8 & 52.3 & {$[21.7(n=3)]$} & 8.6 & $4-5$ \\
\hline Degradation initial (D1) & 10 & - & {$[33.6(n=5)]$} & 37.7 & 38.5 & {$[4.2(n=5)]$} & 0.8 & $2-3$ \\
\hline Degradation advanced (D2) & 4 & 53.3 & - & 49.0 & 49.5 & - & 0.5 & $1-2$ \\
\hline Stabilization initial (SI1) & 16 & - & {$[45.0(n=3)]$} & 46.7 & 47.5 & {$[3.7(n=3)]$} & 0.8 & $2-3$ \\
\hline Stabilization initial (SI2) & 8 & 3.3 & - & 49.9 & 49.9 & - & 0.0 & $1-2$ \\
\hline Stabilization advanced (SA1) & 8 & - & {$[43.3(n=4)]$} & 46.5 & 52.1 & {$[8.8(n=4)]$} & 5.6 & $3-4$ \\
\hline Stabilization advanced (SA2) & 28 & - & {$[44.1(n=24)]$} & 51.7 & 72.0 & {$[23.3(n=24)]$} & 20.3 & $5-6$ \\
\hline Total & 83 & - & {$[42.2(n=39)]$} & 47.5 & 56.0 & {$[17.7(n=39)]$} & 8.6 & 4 \\
\hline
\end{tabular}

Colleen Site (CS)

Undisturbed wedges (UD)

Degradation initial (D1)

Degradation advanced (D2)

Stabilization initial (SI1)

Stabilization initial (SI2)

Stabilization advanced (SA1)

Stabilization advanced (SA2)

Transect T1 total

Transect T2 total

Total

36

Areas affected by development

$\begin{array}{ll}2 & - \\ 5 & - \\ 4 & 31 \\ 11 & 16 \\ 1 & - \\ - & - \\ 23 & - \\ 36 & -\end{array}$

$\begin{array}{lll}- & 55.5 & 60.5 \\ - & 48.2 & 51.0 \\ 31.3 & 45.0 & 47.5 \\ - & 44.1 & 50.7 \\ 16.0 & {[39.1(n=12)]} & 50.5 \\ - & 53.0 & 59.0 \\ - & - & - \\ - & {[40.9(n=22)]} & 47.8 \\ - & 49.2 & 55.2 \\ - & {[44.0(n=35)]} & 51.1\end{array}$

$\begin{array}{ll}60.5 & 67.0 \\ 51.0 & 51.0 \\ 47.5 & 47.5 \\ 50.7 & 52.2 \\ 50.5 & 5 \\ 59.0 & 6 \\ - & \\ 47.8 & 49.0 \\ 55.2 & 60.2 \\ 51.1 & 54.1\end{array}$

\begin{tabular}{llll}
67.0 & 11.5 & 6.5 & 4 \\
51.0 & 2.8 & 0.0 & 2 \\
47.5 & 2.5 & 0.0 & 2 \\
52.2 & 8.1 & 1.5 & 3 \\
56.0 & {$[14.4(n=12)]$} & 5.5 & 4 \\
66.0 & 13.0 & 6.0 & 4 \\
- & - & - & - \\
49.0 & {$[8.1(n=22)]$} & 1.9 & 4 \\
60.2 & 11.1 & 5.0 & 3 \\
\hline 54.1 & {$[9.2(n=35)]$} & 3.0 & \\
\hline
\end{tabular}


Table 3. (concluded).

\begin{tabular}{|c|c|c|c|c|c|c|c|c|}
\hline Stage of degradation stabilization & $\begin{array}{l}\text { Number of } \\
\text { boreholes }(n)\end{array}$ & $\begin{array}{l}\text { Water } \\
\text { depth } \\
(\mathrm{cm})\end{array}$ & $\begin{array}{l}\text { Thaw } \\
\text { depth }^{a} \\
(\mathrm{~cm})\end{array}$ & $\begin{array}{l}\text { Perma-frost } \\
\text { table }^{b}(\mathrm{~cm})\end{array}$ & $\begin{array}{l}\text { Depth to } \\
\text { massive } \\
\text { ice }(\mathrm{cm})\end{array}$ & $\begin{array}{l}\text { Frozen protective } \\
\text { layer (PL1) }{ }^{a, c}(\mathrm{~cm})\end{array}$ & $\begin{array}{l}\text { Intermediate } \\
\text { layer (PL3) }(\mathrm{cm})\end{array}$ & $\begin{array}{l}\text { Vulnerability } \\
\text { level }\end{array}$ \\
\hline \multicolumn{9}{|l|}{ Airport Site (AS) } \\
\hline Undisturbed wedges (UD) & - & - & - & - & - & - & - & - \\
\hline Degradation initial (D1) & 7 & - & 52.4 & 52.6 & 52.6 & 0.1 & 0.0 & 1 \\
\hline Degradation advanced (D2) & 3 & 42.3 & {$[46.0(n=2)]$} & 46.5 & 46.5 & {$[0.3(n=2)]$} & 0.0 & 1 \\
\hline Stabilization initial (SI1) & 2 & - & 63.5 & 64.5 & 64.5 & 1.0 & 0.0 & $1-2$ \\
\hline Stabilization initial (SI2) & 10 & 18.7 & {$[50.9(n=9)]$} & 52.0 & 56.6 & {$[5.4(n=9)]$} & 4.6 & $3-4$ \\
\hline Stabilization advanced (SA1) & - & - & - & - & - & - & - & - \\
\hline Stabilization advanced (SA2) & 4 & - & 63.3 & 65.3 & 85.0 & 21.8 & 19.8 & 5 \\
\hline Transect T3 total & 12 & - & 54.7 & 55.0 & 57.0 & 2.3 & 2.0 & 3 \\
\hline Transect T5 total & 14 & - & {$[53.4(n=12)]$} & 54.1 & 61.3 & {$[9.3(n=12)]$} & 7.2 & 4 \\
\hline Total & 26 & - & {$[54.0(n=24)]$} & 54.5 & 59.3 & {$[5.8(n=24)]$} & 4.8 & $3-4$ \\
\hline
\end{tabular}

${ }^{a}$ Average values [in square brackets] were calculated only for boreholes drilled in the end of July 2012 (for JS), mid-August 2014 (for CS), and mid-September 2015 (for AS); results of drilling in June 2011 (JS) and March 2016 (CS and AS) were excluded from these calculations.

${ }^{b}$ Top of the intermediate layer (based on the analysis of cryostructures).

${ }^{\circ}$ Thickness of frozen soil layer on top of massive ice bodies on the day of drilling (includes the frozen part of the active layer, transient layer, and intermediate layer). 
Fig. 9. Average thicknesses of the intermediate layer (PL3) above massive-ice bodies (left) and depths to massive ice (right) for different stages of ice-wedge degradation/stabilization at the three study sites, Prudhoe Bay area. JS, Jorgenson Site; CS, Colleen Site; and AS, Airport Site.
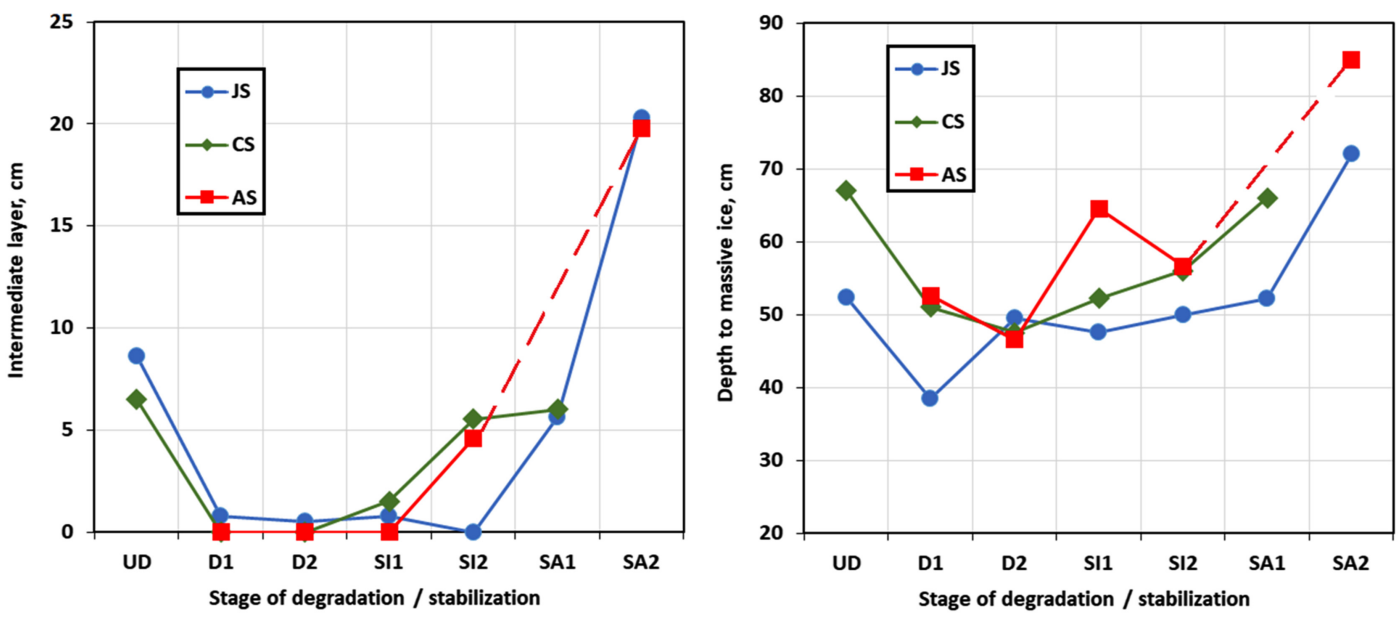

2018) is also occurring at all three sites (Walker et al. 2022). Efforts to revegetate and restore impacted areas in the Prudhoe Bay area are described in several other papers (e.g., Jorgenson and Joyce 1994; Kidd et al. 2006).

Studies at the JS showed that vegetation composition varied widely among stages of the ice-wedge degradation and stabilization (Jorgenson et al. 2015). It was similar for the central parts of ice-wedge polygons and UD sites, where dwarf shrubs (Dryas integrifolia Vahl, Salix arctica Pall., and Salix richardsonii Hook.) were abundant. The DI stage was dominated by sedges (Eriophorum angustifolium Honck. and Carex bigelowii Torr. ex Schwein.). By the DA stage, there was a large shift to the aquatic calcareous mosses (Calliergon giganteum (Schimp.) Kindb. and Scorpidium scorpioides (Hedw.) Limpr.) and forbs (Utricularia vulgaris L. and Hippuris vulgaris L.). At the SI stage, aquatic sedges (Carex aquatilis Wahlenb. and E. angustifolium) dominated. The SA stage had abundant dwarf shrubs similar to UD but differed from the latter by the abundance of the sedge, Carex membranacea Hook.

Formation and deepening of ice-wedge troughs results in the accumulation of snow and water, which leads to an increase in surface and ground temperatures. At the JS, it resulted in an increase in annual mean surface temperature from $-6.2{ }^{\circ} \mathrm{C}$ (UD) to $-1.3^{\circ} \mathrm{C}$ (DA), whereas temperatures at polygon centers were almost $-7.0^{\circ} \mathrm{C}$ (Jorgenson et al. 2015). At the CS and AS, annual mean surface temperatures measured at permanent plots (Walker et al. 2018) were significantly warmer: $-2.3^{\circ} \mathrm{C}$ in troughs $(n=21)$ and $-3.9^{\circ} \mathrm{C}$ at polygon centers $(n=22)$. Average values of annual mean ground temperatures at $40 \mathrm{~cm}$ from the surface in troughs and centers were $-3.7^{\circ} \mathrm{C}(n=21)$ and $-5.0^{\circ} \mathrm{C}(n=22)$, respectively. Warmer temperatures usually corresponded to deeper trough depths, most likely due to increased winter snow accumulation in the deeper troughs. In troughs less than $30 \mathrm{~cm}$ deep, annual mean surface temperatures varied from -1.5 to $-3.8{ }^{\circ} \mathrm{C}$, whereas in deeper troughs they varied from $+0.3^{\circ} \mathrm{C}$ to $-2.5^{\circ} \mathrm{C}$; correlation of annual mean surface temperatures with average snow depths was very similar but correlation with water depth in troughs was not as strong (Fig. S192).

Annual mean ground temperatures measured at 50 (JS) or 40 (CS and AS) $\mathrm{cm}$ below the surface (near permafrost table) were significantly lower than corresponding surface temperatures (Jorgenson et al. 2015, Walker et al. 2018). This thermal offset (Kudryavtsev 1959; 
Burn and Smith 1988; Romanovsky and Osterkamp 1995; Osterkamp and Romanovsky 1999) is caused by differences in the thermal conductivity of soils (especially organic-rich) in frozen and unfrozen states. At the JS, the offset was much higher in deep troughs (average value for DA sites was approximately $2.2^{\circ} \mathrm{C}$ ) than at polygon centers (approximately $1.3^{\circ} \mathrm{C}$ ). At the CS and AS, a similar trend occurred (Fig. $\mathrm{S}^{2} \mathrm{O}^{2}$ ): the average value of thermal offset in troughs was approximately $1.4^{\circ} \mathrm{C}$ (in deepest troughs it sometimes exceeded $2{ }^{\circ} \mathrm{C}$ ), whereas at polygon centers it was approximately $1.1^{\circ} \mathrm{C}$. This difference in the thermal offset values between troughs and centers may be explained by faster accumulation of organic material in troughs and (or) lateral thermal impact from colder polygon centers and by two-dimensionality of the temperature field across the ice wedges.

The increase in surface and ground temperatures triggered by development of deeper ice-wedge troughs is caused by positive feedbacks linked to several factors including deeper snow and water in the troughs and earlier disappearance of snow due to dust near the roads. The connection between trough development and thaw depths is not as obvious, and we see relatively weak correlation between thaw depths and depths of ice-wedge troughs, snow, and water, and annual mean surface temperature. Even a significant increase in temperatures or thickness of snow cover and depth of water usually causes only a slight $(<5-7 \mathrm{~cm})$ increase in thaw depths (Fig. S21 $\left.{ }^{2}\right)$. Interestingly, even in the deepest and warmest trough (permanent plot T3-10) with a surface temperature of $+0.3{ }^{\circ} \mathrm{C}$, water depth of $71 \mathrm{~cm}$, and snow depth of $85 \mathrm{~cm}$, thaw depth was only $60 \mathrm{~cm}$ (less than $4 \mathrm{~cm}$ more than an average value for all troughs at the CS and AS). Average thaw depths in troughs with $>1 \mathrm{~cm}$ of water $(n=17)$ and relatively dry troughs $(n=9)$ were 57.0 and $54.9 \mathrm{~cm}$, respectively. If we exclude one exceptionally deep thaw-depth value (permanent plot T4-25, water depth $31 \mathrm{~cm}$, thaw depth $82 \mathrm{~cm}$ ), average thaw depths in water-filled and dry troughs would be almost identical, which also confirms a very weak correlation between thaw depths and water depths.

Moreover, comparison of thaw depths measured regularly along all Prudhoe Bay transects showed that average thaw depths under the water (measured mainly in water-filled troughs, except T4 where polygonal centers were also partially covered by water) were usually lower than those measured at dry locations, and the difference at some transects could reach almost $11 \mathrm{~cm}$ (Table $S 6^{2}$ ). Such a difference at the CS transects was described in more detail by Walker et al. (2022). Comparison of thaw depths at permanent plots in troughs and polygon centers also showed that the latter were significantly deeper than the former within all CS and AS transects (Table S6 $a^{2}$, Fig. S22 ${ }^{2}$ ), with average values of $56.2 \mathrm{~cm}$ for troughs $(n=24)$ and $64.2 \mathrm{~cm}$ for centers $(n=25)$, whereas average values of annual mean surface temperatures in troughs and centers were $-2.3{ }^{\circ} \mathrm{C}(n=21)$ and $-3.9^{\circ} \mathrm{C}$ $(n=22)$, respectively (i.e., higher temperatures surprisingly correspond to shallower thaw depths). This disparity may be explained by seasonal factors that affect temperatures and thaw depths in different ways: annual mean surface temperatures are mainly affected by winter conditions (e.g., snow depths), whereas thaw depths mostly depend on summer conditions, and the occurrence of thick pond ice in deep troughs results in a significant delay in the beginning of seasonal ground thawing in comparison with shallow troughs and especially with polygon centers.

Studies at the JS also showed that thaw depths in polygon centers were greater than in troughs (Jorgenson et al. 2015). Average thaw depths in ice-wedge troughs at this site varied significantly among stages. In late summer (end of July 2012), they were lower in UD $(37.3 \mathrm{~cm})$ and D1 $(33.6 \mathrm{~cm})$ compared with SI1 $(45.0 \mathrm{~cm})$, SA1 $(43.3 \mathrm{~cm})$, and SA2 $(44.1 \mathrm{~cm})$ (Table 3, Table $\mathrm{S1}^{2}$ ).

This difference in thaw depths in troughs and polygon centers at all study sites may be also related to more organic matter and greater moisture content of soil in ice-wedge 
troughs. In some cases, shallow thaw depths in troughs may be explained by active ice-wedge degradation (D1 and D2 stages) at the time of measurements but our drilling at CS in 2014, which was performed at the same season as thaw-depth measurements (mid-August), showed that only two of 35 studied ice wedges experienced thawing at the time of drilling (both of them were located along Transect 1).

Thus, deepening of troughs leads to significant increases in surface and ground temperatures (Figs. S19 and S20 ${ }^{2}$ ) but not in thaw depths (Fig. S21 ${ }^{2}$ ). This means that the stabilization of ice wedges, which in many cases starts after several years of degradation as a result of accumulation of sediments and organic matter in troughs and subsequent formation of the IL, was not prevented by the accumulation of snow and water in the troughs. We compared the data from all our boreholes that were drilled in ice-wedge troughs through water (or ice) within the JS, CS, and AS transects and could not find any correlation between thicknesses of the IL and water depths (Fig. S23 ${ }^{2}$ ). Although some wedges were either degrading or extremely vulnerable $(\mathrm{IL}=0 \mathrm{~cm})$, others could be very well protected even under deep $(20$ to $70 \mathrm{~cm})$ water.

Previous studies suggested that in the areas of cold continuous permafrost, stabilization of ice wedges, which have been actively degrading beneath deep thermokarst ponds at the intersections of ice wedges, commonly starts when water in troughs is still relatively deep (Jorgenson et al. 2006, 2015; Kanevskiy et al. 2016, 2017). This was confirmed by coring in several 10- to 70-cm-deep ponds (Tables S3, S4 ${ }^{2}$ ). Results of winter coring at Pond Marcel (Borehole T1-74.0) are particularly interesting because this pond has been relatively stable for many decades (at least since 1949, when it was already visible in the oldest available aerial photographs) (Fig. 3A, Fig. S172). This borehole was drilled in March 2016 through the 37$\mathrm{cm}$-thick pond ice, and the total thickness of frozen soil above wedge ice was $86 \mathrm{~cm}$ $\left(\right.$ Table $\mathrm{S}^{2}$ ). Thaw depth in this pond measured on 16 September 2015 was $52 \mathrm{~cm}$, which means that frozen protective layer (PL2) at that time was more than $30 \mathrm{~cm}$. Occurrence of this layer, which includes the ice-rich 17-cm-thick intermediate layer, prevents deepening and expansion of Pond Marcel. This pond is one of several stable thermokarst ponds that have persisted at JS, CS, and AS since 1949. We presume that deep water in this pond has prevented its colonization by aquatic vegetation and eventual succession to a drier habitat, which explains the long-term stability of Pond Marcel and similar ponds.

Ice-wedge degradation under old deep ponds will resume when annual mean ground temperature at the base of the active layer exceeds $0{ }^{\circ} \mathrm{C}$. In the areas with cold continuous permafrost, like the $\mathrm{PBO}$, such a transition is still unlikely at present, although in one of our permanent plots (T3-10, trough depth $116 \mathrm{~cm}$, snow depth $85 \mathrm{~cm}$, water depth $71 \mathrm{~cm}$ ) annual mean surface temperature (July 2015-July 2016) already reached positive values, whereas annual mean ground temperature at $40 \mathrm{~cm}$ was still negative $\left(-0.7^{\circ} \mathrm{C}\right)\left(\right.$ Table $\left.\mathrm{S7}^{2}\right)$.

\section{Stages of ice-wedge degradation/stabilization}

In general, levels of vulnerability of ice wedges to thermokarst are closely related to stages of ice-wedge degradation/stabilization: although Undisturbed ice wedges (UD) and wedges at Stabilization Advanced stages (SA1 and SA2) are relatively well protected by the intermediate layer, wedges at Degradation Initial (D1) and Degradation Advanced (D2) stages have almost no protection (Kanevskiy et al. 2017). This correlation was confirmed by our studies at the JS, CS, and AS (Fig. 9). However, our studies of ice wedges at Prudhoe Bay and other areas of northern Alaska have revealed the complexity associated with identifying the stages of degradation and stabilization. For example, D1, D2, and D3 stages are very unstable and can easily transform into corresponding SI stages and then revert back to corresponding degradation stages (Fig. 1), mainly because of significant interannual fluctuations in thaw depths. As a result, it is very difficult to detect a certain stage based on 
remote sensing and field observations of surficial features (without drilling). We can clearly identify the actual stage by coring at the end of the warm season but only for a particular year, as the changes in thaw depths in another year may easily reverse the process of either degradation or stabilization. Another problem with degradation/stabilization stage identification is related to spatial disparities: the same wedge at the same time may be degrading at one place and stabilizing at another, and the distance between such places may be very small (for example, compare boreholes T5-96.8 and T5-94.5, which are located in the same trough only $2.5 \mathrm{~m}$ apart; see Fig. 8).

SA stages are usually more static but only if a thickness of the intermediate layer is so significant that it requires a large increase in thaw depths to initiate a new degradation cycle at such sites. Fast transition from SI to SA may occur only if a trough is filled with sediments and organic matter very quickly, which cannot happen frequently in deep water-filled troughs. In deep troughs, SI2 and especially SI3 stages may last for many decades and probably even centuries (Table 1), even if ice wedges are already protected by thick IL (like at Pond Marcel/T1-74.0 site), and a new degradation cycle is highly improbable without significant climate warming.

Theoretically, a rapid transition from SI2 and SI3 to corresponding SA stages may also occur as a result of fast growth of aquatic mosses in the bottom of the ponds and formation of thick floating vegetation mats, which has been observed in lakes and ponds in various regions of Alaska (Parsekian et al. 2011). We speculate that when such vegetation mats cover entire surface of thermokarst ponds and their thickness exceeds the ALT, water beneath floating mats can become perennially frozen, and this may lead to relatively fast transformation to SA stages.

This process may explain the formation of near-surface TCI bodies above partially degraded ice wedges. Very often TCI forms at significant depths, but within all Prudhoe Bay study areas we have also observed numerous TCI bodies located right below the permafrost table (Figs. 6 and 8, Figs. S6, S7 ${ }^{2}$ ). Previously Kanevskiy et al. (2017) suggested two possible mechanisms for the formation of such near-surface TCI bodies: (1) some of these bodies could form in thermo-erosional cavities developed inside eroded ice wedges at significant depth, and their present-day near-surface position may be explained by subsequent thermokarst, which has affected the top parts of ice wedges after TCI formation; (2) water-filled cavities could originally form at the permafrost table as a result of thermokarst or thermal erosion, but the upper soil of the active layer (AL) could be protected from collapse by thick and dense vegetation cover and peat layer; further vegetation growth and soil accumulation on the surface resulted in permanent freezing of this shallow water. Probably the above-mentioned process of development of floating vegetation mats with subsequent freezing of water bodies beneath these mats can be considered to be the third possible mechanism, which gives another explanation of formation and preservation of near-surface TCI.

\section{Impact of road infrastructure on ice-wedge degradation and stabilization}

Based on analysis of historical imagery, we can see some differences between patterns of ice-wedge degradation within the relatively undisturbed JS (Fig. S16 ${ }^{2}$ ) and two study areas affected by road infrastructure (CS and AS) (Figs. S17, S18 ${ }^{2}$ ). Prior to the road construction (Spine Road at the CS was constructed in 1969, and Dalton Highway at the AS was constructed in 1974), all study areas had relatively uniform terrain with prevailing low-centered polygons and a few old thermokarst ponds. Widespread degradation of ice wedges at the JS started only in the late 1980s (Fig. S16 ${ }^{2}$ ), whereas ice wedges adjacent to the roads at the CS and AS were already degrading in 1970s (Figs. S17, S18 ${ }^{2}$ ). 
Ice-wedge thermokarst along the roads started as a result of changes in the hydrological regime and accumulation of surface water, dust, and snow near embankments (Walker et al. 1987; Raynolds et al. 2014). With time, ice-wedge degradation accelerated after the very wet and warm summer of 1998. Degradation of ice wedges along Transect 2 at the CS and Transect 5 at the AS was more active for many years due to annual flooding events. At the CS and AS, ice-wedge thermokarst triggered by development was accelerated by changing climate, whereas at the JS ice-wedge thermokarst has been driven mainly by climatic factors.

Our study shows that ice-wedge degradation in the continuous permafrost zone is a reversible process not only in undisturbed areas (Jorgenson et al. 2006, 2015; Kanevskiy et al. 2017) but in the areas affected by infrastructure. Despite the strong influence of the road infrastructure on the active layer and the upper permafrost stability through changes in hydrology and surface conditions, numerous wedges at the CS and AS have already experienced stabilization. In comparison with the relatively undisturbed JS, CS and AS had smaller average thicknesses of the IL due to more active degradation during the last decades. Some stages (UD, SA1, SA2) at the CS and AS were poorly represented (Table 3), which also may explain small average thicknesses of the intermediate layer at these sites. However, average thicknesses of the IL for SI2 stage in these areas were significantly larger than those of the JS (Table 3, Fig. 9).

Although thermokarst is usually more severe in flooded areas, higher plant productivity, more litter, and mineral material (road dust and material eroded from polygon centers) accumulating in the troughs contribute to formation of the intermediate layer, which protects ice wedges from further thawing. As a result, ice wedges under the deep water-filled troughs along T2 and T5 transects in many cases were more stable at the time of our study than the wedges along T1 transect, which had not been affected by flooding, and T3 transect, located within well-drained terrain adjacent to the riverbank. Moreover, no degradation stages (D1 and D2) were detected at T2. In general, the ice wedges along T2 (even the wedges under deep troughs filled with water) were much more stable than the wedges along T1 (Table $\mathrm{S3}^{2}$ ), although thermokarst had been much more active along T2 during initial degradation. Similarly, no D1 stage was detected at T5, and only two wedges were degrading there under deep troughs (D2 stage) in September 2015.

At the JS, the IL under water-filled troughs was practically absent, which is the sign of active thermokarst. Average water depth for 13 water-filled troughs was $22.9 \mathrm{~cm}$, and the average IL thickness was only $0.4 \mathrm{~cm}$. Nine of 13 ice wedges $(69 \%)$ were not protected by the IL, and the remaining four ice wedges were poorly protected by a very thin IL. At the CS and AS, 26 water-filled troughs had an average water depth of $25.6 \mathrm{~cm}$, and average IL was $4.3 \mathrm{~cm}$. Only 9 ice wedges of 26 (35\%) were not protected by the intermediate layer, and most of them were located within T1, where 5 wedges of 6 were not protected. Thicknesses of the IL in the remaining 17 ice-wedge troughs varied from 2 to $19 \mathrm{~cm}$. Ice wedges with the thickest IL were located not far from the road, so we suggest that dust accumulation is a major factor for their stabilization. We did not find any distinctive correlation between thicknesses of the IL under water-filled troughs and the depth of water (Fig. S23 ${ }^{2}$ ).

Thus, ice wedges located in water-filled troughs at the JS were much less protected in comparison with those from the CS and AS, whereas overall protection of ice wedges (located beneath both dry and water-filled troughs) at the JS was much better with the average IL thickness of $8.6 \mathrm{~cm}(\mathrm{n}=83)$, compared with $3.0 \mathrm{~cm}(n=36)$ at the $\mathrm{CS}$ and $4.8 \mathrm{~cm}(n=26)$ at the AS (Tables 2 and 3, Fig. 5A). At the CS and AS, most of the ice wedges beneath the water-filled troughs were well protected (SI2 stage), and many of them had well-developed ILs. Unprotected ice wedges were encountered mainly within "dry" T1, where the surface conditions were similar to those of the JS. At frequently flooded "wet" T2, almost all wedges 
in water-filled troughs had well-developed IL (Table S3 ${ }^{2}$ ). At T5, numerous wedges were well protected, and only one was degrading in mid-September 2015. At "dry" T3, well drained by the river, only two wedges were drilled in water-filled troughs, and none of them was degrading in mid-September 2015 (though one of them had only 0.5-cm-thick frozen protective layer), whereas numerous wedges in deep dry troughs located along the same transect were degrading at that time. At "wet" T5, numerous wedges were well protected, and only one was thawing in mid-September 2015 (Table S4 ${ }^{2}$ ). Only 30\% of ice wedges at the "wet" $\mathrm{T} 2$ and $\mathrm{T} 5$ transects were not protected from thawing $(\mathrm{IL}<1 \mathrm{~cm})$, in comparison with $\sim 45 \%$ at the JS, and $\sim 80 \%$ at the "dry" T1 and T3 transects (Fig. $5 \mathrm{~B}$ ). We presume that ice wedges in water-filled troughs at the CS and AS were protected by thicker intermediate layers because ice-wedge thermokarst here started earlier, which has resulted in accumulation of more soil and organic matter than at the JS.

To estimate the influence of the road infrastructure on the ice-wedge thermokarst at the CS and AS study areas, we compared thicknesses of the IL above all studied ice wedges, within four transects (T1, T2, T3, and T5) at different distances from the Spine Road (T1 and T2) and Dalton Highway (T3 and T5). We did not find any distinctive correlations, and degrading ice wedges, which were not protected by an IL, occurred at all distances from the roads (Fig. S24 ${ }^{2}$ ). However, several well-protected ice wedges (with the IL 5 to $20 \mathrm{~cm}$ thick), most of which were encountered at T2 and T3, are located very close $(<30 \mathrm{~m})$ to the roads, and general trends for all four transects reveal a slight increase in thicknesses of the IL closer to the roads (Figs. S25, S26 ${ }^{2}$ ).

Occurrence of well-protected ice wedges very close to the roads may be explained by rapid accumulation of road dust. Traditionally, road dust has been considered to be a very important factor triggering and accelerating ice-wedge thermokarst, mainly because early snowmelt, which is caused by dark-colored road dust that accumulates near the road, contributes to roadside flooding, increased soil temperatures, and deeper summer thaw along the roads (Benson et al. 1975; Everett 1980b; Walker and Everett 1987; Walker et al. 1987, 2015; Raynolds et al. 2014). However, our study shows that road dust near to the road also creates negative feedbacks to wedge ice degradation via rapid soil accumulation in troughs that eventually leads to increase in thickness of protective layers and termination of ice-wedge thermokarst.

\section{Conclusions}

Ice-wedge degradation in the $\mathrm{PBO}$ is controlled by climate, topography, vegetation, surface and groundwater, soil properties, and development disturbances of various types that create positive and negative feedbacks. At sites affected by development, ice-wedge thermokarst started practically simultaneously with development and was later intensified by climate change, whereas in undisturbed areas ice-wedge thermokarst has been driven mainly by climatic factors.

The quasi-cyclic process of ice-wedge degradation and stabilization is regulated by structure, properties, and thicknesses of soil layers above ice wedges, which include the active, transient, and intermediate layers. Vulnerability of ice wedges to thermokarst may be determined from the thickness and properties of protective layers of frozen soils above ice wedges.

Occurrence of the ice-rich intermediate layer indicates the long-term stability of ice wedges. Thickness of the intermediate layer strongly depends on a stage of ice-wedge degradation/stabilization. Stabilized ice wedges have thicker intermediate layer on top of them (usually $\sim 2$ times thicker than the intermediate layer above undegraded wedges) and, therefore, are less vulnerable to thermokarst. 
Deepening of troughs during ice-wedge degradation leads to a substantial increase in surface and ground temperatures but not in thaw depths. Thus, stabilization of ice wedges, which commonly starts after several years of degradation as a result of accumulation of sediments and organic matter and fast growth of vegetation, is not prevented by the accumulation of snow and water in the troughs. In deep thermokarst ponds, stabilization of actively degrading ice wedges starts under the water, as indicated by occurrence of an icerich intermediate layer above partially-degraded ice wedges.

Although thermokarst is usually more severe in flooded areas, higher plant productivity, more litter, and mineral material accumulating in the water-filled troughs contributed to the formation of the intermediate layer, which protects ice wedges from further thawing better than in relatively dry areas.

Despite a strong influence of infrastructure on the active-layer thickness and stability of the upper permafrost through changes in hydrology and surface conditions, ice-wedge degradation and stabilization are reversible processes in both disturbed and undisturbed areas. Ice wedges in water-filled troughs in the areas affected by development are less vulnerable than in undisturbed areas because ice-wedge thermokarst here started earlier, which resulted in accumulation of more soil (and especially road dust) and organic matter.

\section{Funding statement}

This work was funded by the National Science Foundation (NSF grants ArcSEES-1233854, ARC-1023623, OPP-1722572, OPP-1820883, OPP-1806213, NNA-1928237).

\section{Data availability statement}

Data are available through the NSF-funded Arctic Data Center (https://arcticdata.io/ catalog/view/doi\%3A10.18739\%2FA25W5K; https://arcticdata.io/catalog/view/doi\%3A10.18739\% 2FA28K74X6T; https://arcticdata.io/catalog/view/doi\%3A10.18739\%2FA2VM42Z20).

\section{Acknowledgements}

James “Tripp” Collier, Karen Jorgenson, Joshua Koch, Nataliya Moskalenko, Dana Brown, Katie Nicolato, Kimberly Wickland, Ksenia Ermokhina, Lisa Wirth, Howard Epstein, Kelcy Kent, and Claire Griffin took part in fieldwork. Logistical support was provided by CH2MHill Polar Services. We thank Associate Editor Dr. Frédéric Bouchard and two anonymous reviewers for their helpful comments and suggestions.

\section{References}

Abolt, C.J., Young, M.H., Atchley, A.L., Harp, D.R., and Coon, E.T. 2020. Feedbacks between surface deformation and permafrost degradation in ice wedge polygons, Arctic Coastal Plain, Alaska. J Geophys Res: Earth Surface, 125: e2019JF005349. doi: 10.1029/2019JF005349.

Benson, C., Holmgren, B., Timmer, R., Weller, G., and Parrish S. 1975. Observations on the seasonal snow cover and radiation climate at Prudhoe Bay, Alaska during 1972. In Ecological investigations of the Tundra Biome at Prudhoe Bay, Alaska. Edited by J. Brown. Biological Papers of the University of Alaska, Special Report 2, Fairbanks, AK. pp. 12-50.

Bjorkman, A.D., Myers-Smith, I.H., Elmendorf, S.C., et al. 2018. Plant functional trait change across a warming tundra biome. Nature, 562(7725): 57-62. doi: 10.1038/s41586-018-0563-7. PMID: 30258229.

Black, R.F. 1983. Three superimposed systems of ice wedges at McLeod Point, northern Alaska, may span most of Wisconsinan stage and Holocene. National Academy Press, Washington, DC. 68-73 pp.

Bray, M.T., French, H.M., and Shur, Y. 2006. Further cryostratigraphic observations in the CRREL permafrost tunnel, Fox, Alaska. Permafrost Periglacial Processes 17(3): 233-243. doi: 10.1002/ppp.558.

Brown, J., and Sellmann, P.V. 1973. Permafrost and coastal plain history of arctic Alaska. In Alaskan Arctic tundra. Technical Paper No. 25. Edited by M.E. Britton. Arctic Institute of North America, Calgary, Canada. 31-47 pp.

Buchhorn, M., Raynolds, M.K., Kanevskiy, M., Matyshak, G., Shur, Y., Willis, M.D., et al. 2016. Effects of 45 years of heavy road traffic and climate change on the thermal regime of permafrost and tundra at Prudhoe Bay, Alaska. University of Alaska, Anchorage. 1221-1222 pp. 
Burn, C.R., and Smith, C.A.S. 1988. Observations of the "thermal offset" in the near-surface mean annual ground temperature at sites near Mayo, Yukon Territory, Canada. Arctic, 41(2): 99-104. doi: 10.14430/arctic1700.

CALM database. 2021. Available from https://www2.gwu.edu/ calm/data/north.htm [accessed 19 Mar. 2022].

Christiansen, H.H., Matsuoka, N., and Watanabe, T. 2016. Progress in understanding the dynamics, internal structure and palaeoenvironmental potential of ice wedges and sand wedges. Permafrost and Periglacial Processes, 27: 365-376. doi: 10.1002/ppp.1920.

Elmendorf, S.C., Henry, G.H., Hollister, R.D., et al. 2011. Global assessment of experimental climate warming on tundra vegetation: heterogeneity over space and time. Ecology Letters, 15(2): 164-175. doi: 10.1111/j.14610248.2011.01716.x. PMID: 22136670.

Everett, K.R. 1980a. Landforms. In Geobotanical Atlas of the Prudhoe Bay Region, Alaska. CRREL Report 80-14. Edited by D.A. Walker, K.R. Everett, P.J. Webber, J. Brown. U.S. Army Corps of Engineers, Cold Regions Research and Engineering Laboratory, Hanover, NH, pp. 14-19.

Everett, K.R. 1980b. Soils. Geobotanical Atlas of the Prudhoe Bay Region, Alaska, CRREL Report 80-14. U.S. Army Corps of Engineers, Cold Regions Research and Engineering Laboratory, Hanover, NH. 20-23 pp.

Farquharson, L.M., Romanovsky, V.E., Cable, W.L., Walker, D.A., Kokelj, S.V., and Nicolsky, D. 2019. Climate change drives widespread and rapid thermokarst development in very cold permafrost in the Canadian High Arctic. Geophys Res Lett, 46(12): 6681-6689. doi: 10.1029/2019GL082187.

Fortier, D., Kanevskiy, M., and Shur, Y. 2008. Genesis of reticulate-chaotic cryostructure in permafrost. Institute of Northern Engineering, University of Alaska Fairbanks, Anchorage. pp. 451-456.

French, H., and Shur, Y. 2010. The principles of cryostratigraphy. Earth-Sci Rev 101: 190-206. doi: 10.1016/ j.earscirev.2010.04.002.

Frost, G.V., Christopherson, T., Jorgenson, M.T., Liljedahl, A.K., Macander, M.J., Walker, D.A., and Wells, A.F. 2018. Regional patterns and asynchronous onset of ice-wedge degradation since the mid-20th century in Arctic Alaska. Remote Sensing 10: 1312. doi: 10.3390/rs10081312.

Godin, E., Fortier, D., and Lévesque, E. 2016. Nonlinear thermal and moisture response of ice-wedge polygons to permafrost disturbance increases heterogeneity of high Arctic wetland. Biogeosciences 13(5): 1439-1452. doi: $10.5194 /$ bg-13-1439-2016.

Jones, B.M., Grosse, G., Arp, C.D., Liu, L., Miller, E.A., Hayes, D.J., and Larsen, C. 2015. Recent arctic tundra fire initiates widespread thermokarst development. Sci Rep 5: 15865. doi: 10.1038/srep15865. PMID: 26511650.

Jorgenson, M.T. 2011. Coastal region of northern Alaska, Guidebook to permafrost and related features. Alaska Division of Geological \& Geophysical Surveys Guidebook, Anchorage. 188 p.

Jorgenson, M.T., and Joyce, M.R. 1994. Six strategies for rehabilitating land disturbed by oil development in arctic Alaska. Arctic, 47(4): 374. doi: 10.14430/arctic1311.

Jorgenson, M.T., Shur, Y.L., and Pullman, E.R. 2006. Abrupt increase in permafrost degradation in Arctic Alaska. Geophys Res Lett 25(2): L02503.

Jorgenson, M.T., Romanovsky, V.E., Harden, J.W., Shur, Y., O’Donnell, J.A., Schuur, E.A.G., and Kanevskiy, M.Z. 2010. Resilience and vulnerability of permafrost to climate change. Can J Forest Res 40: 1219-1236. doi: 10.1139/X10-060.

Jorgenson, T., Kanevskiy, M.Z., Shur, Y., Moskalenko, N.G., Brown, D.R.N., Wickland, K., Striegl, R., and Koch, J. 2015. Ground ice dynamics and ecological feedbacks control ice-wedge degradation and stabilization. JGR Earth Surface 120(11): 2280-2297. doi: 10.1002/2015JF003602.

Kanevskiy, M., Fortier, D., Shur, Y., Bray, M., Jorgenson, T. 2008. Detailed cryostratigraphic studies of syngenetic permafrost in the winze of the CRREL Permafrost Tunnel, Fox, Alaska. Institute of Northern Engineering, University of Alaska Fairbanks, Anchorage. 889-894 pp.

Kanevskiy, M.Z., Shur, Y., Jorgenson, M.T., Ping, C-L., Michaelson, G.J., Fortier, D., et al. 2013. Ground ice in the upper permafrost of the Beaufort Sea Coast of Alaska. Cold Regions Sci Technol 85: 56-70. doi: 10.1016/ j.coldregions.2012.08.002.

Kanevskiy M., Shur, Y., Walker, D.A., Buchhorn, M., Jorgenson, T., Matyshak, G., et al. 2016. Evaluation of Risk of Ice-Wedge Degradation. Prudhoe Bay Oilfield, Alaska. 999-1001 pp.

Kanevskiy, M., Shur, Y., Jorgenson, T., Brown, D.R.N., Moskalenko, N.G., Brown, J., et al. 2017. Degradation and stabilization of ice wedges: Implications for assessing risk of thermokarst in northern Alaska. Geomorphology 297: 20-42. doi: 10.1016/j.geomorph.2017.09.001

Kidd, J.G., Streever, W., and Jorgenson, M.T. 2006. Site characteristics and plant community development following partial gravel removal in an Arctic oilfield. Arctic Alpine Res, 38(3): pp. 384-393. doi: 10.1657/1523-0430(2006) 38[384:SCAPCD]2.0.CO;2.

Koch, J.C., Jorgenson, M.T., Wickland, K.P., Kanevskiy, M., and Striegl, R. 2018. Ice wedge degradation and stabilization impact water budgets and nutrient cycling in Arctic trough ponds. J Geophys Res: Biogeosci 123: 2604-2616. doi: 10.1029/2018JG004528.

Kokelj, S.V., Lantz, T.C., Wolfe, S.A., Kanigan, J.C., Morse, P.D., Coutts, R., et al. 2014. Distribution and activity of ice wedges across the forest-tundra transition, Western Arctic Canada. J Geophys Res: Earth Surface, 119(9): 2032-2047. doi: 10.1002/2014JF003085.

Kudryavtsev, V.A. 1959. Temperatura, moshchnost' i preryvistost' tolshch merzlykh porod (Temperature, thickness, and discontinuity of permafrost). In Osnovy geokriologii merzlotovedeniya) (Fundamentals of Geocryology (Permafrost Science)), Part 1. Edited by P.F. Shvetsov, B.N. Dostovalov. USSR Academy of Sciences, Moscow. 219-273 pp.

Lachenbruch, A.H., Sass, J.H., Lawver, L.A., Brewer, M.C., Marshall, B.V., Munroe, R.J., et al. 1988. Temperature and depth of permafrost on the Arctic slope of Alaska. In Geology and exploration of the National Petroleum 
Reserve in Alaska, 1974 to 1982. Edited by G. Gryc. U.S. Geological Survey Professional Paper 1399, Washington, DC. pp. 645-656.

Lara, M.J., McGuire, A.D., Euskirchen, E.S., Tweedie, C.E., Hinkel, K.M., Skurikhin, A.N., et al. 2015. Polygonal tundra geomorphological change in response to warming alters future $\mathrm{CO} 2$ and $\mathrm{CH} 4$ flux on the Barrow Peninsula. Global Change Biol, 21: 1634-1651. doi: 10.1111/gcb.12757 PMID: 25258295.

Leffingwell, E. de K. 1919. The Canning River region, Northern Alaska. U.S. Geological Survey professional paper 109. United States Government Printing Office, Washington, $251 \mathrm{pp}$.

Liljedahl, A.K, Boike, J., Daanen, R.P., Fedorov, A.N., Frost, G.V., Grosse, G., et al. 2016. Pan-Arctic ice-wedge degradation in warming permafrost and its influence on tundra hydrology. Nature Geoscience, 9: 312-318. doi: 10.1038/ngeo2674.

Mackay, J.R. 1997. A full-scale field experiment (1978-1995) on the growth of permafrost by means of lake drainage, western Arctic coast: a discussion of the method and some results. Can J Earth Sci 34: 17-33. doi: 10.1139/e17-002.

Mackay, J.R. 2000. Thermally induced movements in ice-wedge polygons, western Arctic coast: a long-term study. Geographie Physique et Quaternaire 54(1): 41-68. doi: 10.7202/004846ar.

Murton, J.B. 2013. Ground ice and cryostratigraphy. Treatise on geomorphology. Academic Press, San Diego, CA. 173-201. pp.

Myers-Smith, I.H., Elmendorf, S.C., Beck, P.S.A., et al. 2015. Climate sensitivity of shrub growth across the tundra biome. Nature Climate Change 5(9): 887-891. doi: 10.1038/nclimate2697.

Osterkamp, T.E., and Romanovsky, V.E. 1999. Evidence for warming and thawing of discontinuous permafrost in Alaska. Permafrost and Periglacial Processes 10: 17-37. doi: 10.1002/(SICI)1099-1530(199901/03)10:1<17::AIDPPP303>3.0.CO;2-4.

Parsekian, A.D., Jones, B.M., Jones, M., Grosse, G., Walter Anthony, K.M., and Slater, L. 2011. Expansion rate and geometry of floating vegetation mats on the margins of thermokarst lakes, northern Seward Peninsula, Alaska, USA. Earth Surface Processes and Landforms 36: 1889-1897. doi: 10.1002/esp.2210.

Pollard, W., Ward, M., and Becker, M. 2015. The Eureka Sound lowlands: an ice-rich permafrost landscape in transition. GeoQuebec, Quebec City, Quebec, Canada. Available from https://members.cgs.ca/documents/ conference2015/GeoQuebec/papers/402.pdf.

Rawlinson, S.E. 1993. Surficial geology and morphology of the Alaskan central Arctic Coastal Plain. Alaska Division of Geological \& Geophysical Surveys Report of Investigation 93-1, Fairbanks, 172 pp.

Raynolds, M.K., Walker, D.A., Ambrosius, K.J., Brown, J., Everett, K.R., Kanevskiy, M., et al. 2014. Cumulative geoecological effects of 62 years of infrastructure and climate change in ice-rich permafrost landscapes, Prudhoe Bay Oilfield, Alaska. Global Change Biology 20(4): 1211-1224. doi: 10.1111/gcb.12500. PMID: 24339207.

Romanovsky, V.E., and Osterkamp, T.E. 1995. Interannual variations of the thermal regime of the active layer and near-surface permafrost in Northern Alaska. Permafrost and Periglacial Processes 6(4): 313-335. doi: 10.1002/ ppp.3430060404.

Romanovsky, V.E., Smith, S.L., Isaksen, K., Shiklomanov, N.I., Streletskiy, D.A., Kholodov, A.L., et al. 2016. Terrestrial Permafrost (in "State of the Climate in 2015"). Bull Am Meteorol Soc, 97: S149-S152.

Romanovsky, V.E., Smith, S.L., Shiklomanov, N.I., Streletskiy, D.A., Isaksen, K., Kholodov, A.L., et al. 2017. Terrestrial permafrost (in "State of the climate in 2016"). Bull Am Meteorol Soc, 98: S147-S149.

Shiklomanov, N., Streletskiy, D., and Nelson, F. 2012. Northern hemisphere component of the Global Circumpolar Active Layer Monitoring (CALM) Program. The Northern Publisher, Salekhard, Russia. 377-382 pp.

Shumskii, P.A. 1959. Ground (subsurface) ice. Principles of Geocryology, Part I, General Geocryology. Academy of Sciences of the USSR, Moscow, pp. 274-327. Chapter IX, (in Russian) (English translation: C. de Leuchtenberg, 1964, National Research Council of Canada, Ottawa, Technical Translation 1130, 118 pp.).

Shur, Y.L. 1975. On the transient layer. Methods of Geocryological Studies, USSR Institute of Hydrogeology and Engineering Geology, Moscow. 82-85 pp.

Shur, Y.L. 1988. The upper horizon of permafrost soils. Tapir Publishers, Trondheim, Norway, 867-871 pp.

Shur, Y., Jorgenson, M.T., and Pullman E.R. 2003. Widespread degradation of ice wedges on the Arctic Coastal Plain in Northern Alaska in response to the recent warmer climate. Eos Trans, 84946), Fall Meet. Suppl., Abstract C11A-05.

Shur, Y.L., French, H.M., Bray, M.T., and Anderson, D.A. 2004. Syngenetic permafrost growth: Cryostratigraphic observations from the CRREL tunnel near Fairbanks, Alaska. Permafrost and Periglacial Processes 15(4): 339-347. doi: 10.1002/ppp.486.

Shur, Y., Hinkel, K.M., and Nelson, F.E. 2005. The transient layer: implications for geocryology and climate-change science. Permafrost and Periglacial Processes 16(1): 5-17. doi: 10.1002/ppp.518.

Shur, Y.L., and Jorgenson, M.T. 2007. Patterns of permafrost formation and degradation in relation to climate and ecosystems. Permafrost and Periglacial Processes 18: 7-19. doi: 10.1002/ppp.582

Shur, Y., Jorgenson, M.T., and Kanevskiy, M.Z. 2011. Permafrost. In Encyclopedia of earth sciences series, encyclopedia of snow, ice and glaciers. Edited by V.P. Singh, P. Singh, and U.K. Haritashya. Springer: Dordrecht, The Nederlands. pp. 841-848.

Shur, Y., Kanevskiy, M., Jorgenson, T., Dillon, M., Stephani, E., and Bray, M. 2012. Permafrost degradation and thaw settlement under lakes in yedoma environment. The Northern Publisher, Salekhard, Russia. 383-388 pp.

Shur, Y., Kanevskiy, M., Walker, D.A., Jorgenson, T., Buchhorn, M., Raynolds, M.K., and Toniolo, H. 2016. Permafrostrelated causes and consequences of the Sagavanirktok river flooding in spring 2015. pp. 1021-1023. Available from https://www.geobotany.uaf.edu/library/talks/Shur2016_ICOP_flooding_tal20160615.pdf. 
Streletskiy, D.A., Shiklomanov, N.I., Nelson, F.E., and Klene, A.E. 2008. Thirteen years of observations at Alaskan CALM sites: long-term active layer and ground surface temperature trends. Institute of Northern Engineering, University of Alaska Fairbanks, Anchorage. 1727-1732 pp.

Swanson, D. 2016. Stability of ice-wedges in Kobuk Valley National Park and the Noatak National Preserve, 1951-2009. Natural Resource Report NPS/ARCN/NRR—2016/1248. doi: 10.13140/rg.2.2.28422.16966.

The Alaska Climate Research Center University of Alaska Fairbanks. Climate Normals, 1981-2010. http:// climate.gi.alaska.edu/Climate/Normals.

Walker, D.A. 1985. Vegetation and environmental gradients of the Prudhoe Bay Region, Alaska. U.S. Army Cold Regions Research and Engineering Laboratory. Hanover, NH.

Walker, D.A., and Everett, K.R. 1987. Road dust and its environmental impact on Alaskan taiga and tundra. Arctic and Alpine Research, 19: 479-489. doi: 10.2307/1551414.

Walker, D.A., and Everett, K.R. 1991. Loess ecosystems of northern Alaska: regional gradient and toposequence at Prudhoe Bay. Ecol Monogr, 61(4): 437-464. doi: 10.2307/2937050.

Walker, D.A., and Webber, P.J. 1980. Vegetation. In Geobotanical Atlas of the Prudhoe Bay Region, Alaska. CRREL Report 80-14. Edited by D.A. Walker, K.R. Everett, P.J. Webber, J. Brown. U.S. Army Corps of Engineers, Cold Regions Research and Engineering Laboratory, Hanover, NH, pp. 24-34.

Walker, D.A., Everett, K.R., Webber, P.J., and Brown, J. 1980. Geobotanical atlas of the Prudhoe Bay region, Alaska. CRREL Report 80-14. Cold Regions Research and Engineering Laboratory, Hanover, NH. 68 pp. Available from http:// acwc.sdp.sirsi.net/client/en_US/search/asset/1027400;jsessionid=6F5EF40051DE66DA706D4275CB11F7D1.enterprise15000.

Walker, D.A., Webber, P.J., Binnian, E.F., Everett, K.R., Lederer, N.D., Nordstrand, E.A., and Walker, M.D. 1987. Cumulative impacts of oil fields on Northern Alaskan landscapes. Science 238(4828): 757-761. doi: 10.1126/ science.238.4828.757. PMID: 17814703.

Walker, D.A., Raynolds, M.K., Shur, Y., Kanevskiy, M., Ambrosius, K.J., Romanovsky, V.E., et al. 2014. Landscape and permafrost changes in the Prudhoe Bay Oilfield, Alaska. In Alaska Geobotany Center Data Report AGC 15-01. Edited by D.A. Walker, M.K. Raynolds, Buchhorn, M. and J.L. Peirce. Institute of Arctic Biology, University of Alaska Fairbanks, Fairbanks, AK. 84 pp.

Walker, D.A., Buchhorn, M., Kanevskiy, M., Matyshak, G.V., Raynolds, M.K., Shur, Y., and Wirth, L.M. 2015. Infrastructure-Thermokarst-Soil-Vegetation interactions at Lake Colleen Site A, Prudhoe Bay, Alaska. In Alaska Geobotany Center Data Report AGC 15-01. Edited by D.A. Walker, M. Kanevskiy, M.K. Raynolds, Buchhorn, M. and J.L. Peirce. Institute of Arctic Biology, University of Alaska Fairbanks, Fairbanks, AK. 92 pp.

Walker, D.A., Kanevskiy, M., Shur, Y., Raynolds, M.K., Buchhorn, M., and Wirth, L.M. 2016. Road effects at Airport study site, Prudhoe Bay, Alaska. In Alaska Geobotany Center Data Report AGC 16-01. Edited by D.A. Walker, M. Kanevskiy, M.K. Raynolds and J.L. Peirce. Institute of Arctic Biology, University of Alaska Fairbanks, Fairbanks, AK. 74 pp.

Walker, D.A., Kanevskiy, M., Shur, Y., Raynolds, M.K., Peirce J.L., Buchhorn, M., et al. 2018. Snow, thaw, temperature, and permafrost borehole data from the Colleen and Airport sites, Prudhoe Bay, and photos of Quintillion Fiber Optic Cable Impacts, North Slope, Alaska. In Alaska Geobotany Center Data Report AGC 18-01. Edited by D.A. Walker, M. Kanevskiy, M.K. Raynolds and J.L. Peirce. Institute of Arctic Biology, University of Alaska Fairbanks, Fairbanks, AK. 66 pp.

Walker, D.A., Raynolds, M.K., Kanevskiy, M., Shur, Y., Romanovsky, V.E., Buchhorn, M., et al. 2022. Cumulative impacts of a gravel road and climate change in an ice-wedge polygon landscape, Prudhoe Bay, Alaska. Arctic Science. doi: 10.1139/as-2021-0014.

Wickland, K.P., Jorgenson, M.T., Koch, J.C., Kanevskiy, M., and Striegl, R.G. 2020. Carbon dioxide and methane flux in a dynamic Arctic tundra landscape: Decadal-scale impacts of ice wedge degradation and stabilization. Geophys Res Lett, 47: e2020GL089894. doi: 10.1029/2020GL089894. 